\title{
Review of Single-Phase Magnetoelectric Multiferroic Thin Film and Process
}

\author{
Hong Goo Yeo ${ }^{\dagger}$ \\ Department of Advanced Materials Engineering, Sun Moon University \\ Asan, Chungnam, South Korea, 31460
}

\section{단일상 자기-전기 다강체 박막 및 공정에 대한 연구동향}

\author{
여홍구 ${ }^{\dagger}$ \\ 선문대학교 신소재공학과
}

(Received August 30, 2021; Revised September 6, 2021; Accepted September 8, 2021)

\begin{abstract}
s
Advance in the growth and characterization of multiferroic thin film promises new device application such as next generation memory, nanoelectronics and energy harvesting. In this review, we provide a brief overview of recent progress in the growth, characterization and understanding of thin-film multiferroics. Driven by the development of thin film growth techniques, the ability to produce high quality multiferroic thin films offers researchers access to new phase and understanding of these materials. We discuss that epitaxial strain and atomic-level engineering of chemistry determine the muliferroic thin film properties. We then discuss the new structures and properties of non-equilibrium phases which is stabilized by strain engineering.
\end{abstract}

Keywords: Multiferroic, Magnetoelectric effect, Thin-film deposition, Epitaxial strain

\section{1. 서론}

광범위한 결정구조와 다양한 특성을 가지고 있는 복 합 산화물(complex oxides)계 중 강성(ferroic)을 두개
또는 그 이상이 동시에 존재하는 다강성(multiferroic) 에 대한 연구가 지난 십 수년간 다강성 재료의 합성 및 물리적 현상을 바탕으로 많은 연구들이 진행되고 있다. 여기서 강성은 일반적으로 재료 내에 유전성, 자성 및

†Corresponding Author: hgyeo2021@sunmoon.ac.kr 


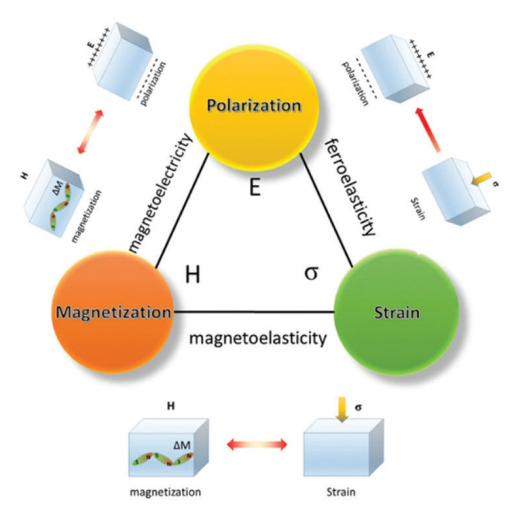

(a)

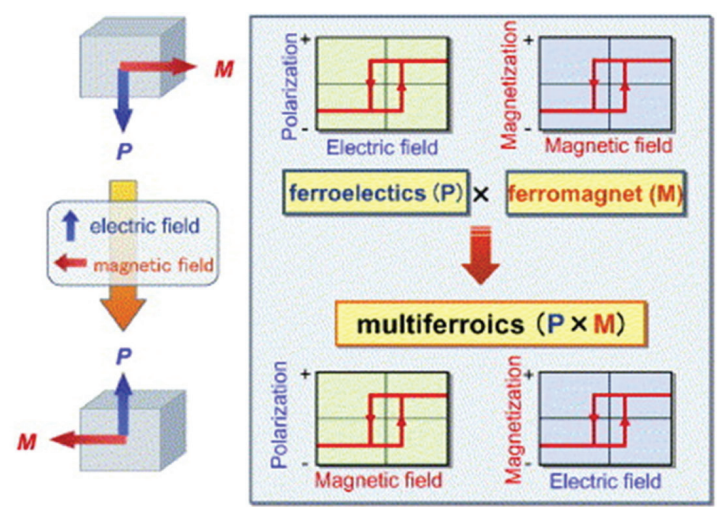

(b)

Fig. 1. (a) Interaction among polarization, magnetization, and strain in multiferroic thin films under external stimuli: electric field (E), magnetic field $(H)$, and stress $(\sigma)$. Source from Jia, et al. Scientific reports 2016;6:1-9, [1]. (b) Multiferroics and magnetoelectric control. Adapted from Tokura J. Magn. Magn. Mater. 2007;310:1145-1150, with permission of Elsevier [2].

탄성과 같은 변수가 외부 에너지(전기장, 자기장, 변형) 에 의해 전환되어 안정된 상태로 존재하는 것을 의미하 며, 이러한 특성을 강유전성, 강자성, 강탄성이라고 일 컫는다. 그리고 일부 강성을 보여지는 재료들에서 강성 들 간의 결합(magnetoelectricity, magnetoelasticity, ferroelasticity)들이 Fig. 1(a)과 같이 보여진다. 1) 최근 들어 다강체 분야에서 $3 \mathrm{~d}^{5}$ 오피탈 준위를 가지는 $\mathrm{Fe}^{3+}$ 간의 초교환(superexchange) 상호작용으로 보여지는 반강자성(antiferromagnetism)도 이 강자성 범주에 포 함시키고 있으며 대표적으로 $\mathrm{BiFeO}_{3}$ 물질이 있다.

이러한 다강성 재료 중에 전기적 특성과 자기적 특 성 간의 상호 깊은 결합 관계를 보여주는 것을 자기-전 기 효과(magnetoelectric effect (ME))라고 한다(Fig. 1(b)). ${ }^{3)}$ 기본적으로 자기-전기 효과를 보이는 다강체에 대한 분극과 자화에 대한 이해를 크게 네 가지 메커니즘 (mechanism)으로 설명하고 있다. Lone-pair 메커니 즘, 기하학적 원자의 배치에 따른 강유전성, 결정 격자 내에 규칙적인 초격자(superlattice)로 이루어진 결정 격자 내에 주이온의 가전자가 불균일하게 분포되어 있 는 경우 그리고 반전 대칭성이 깨짐에 따른 스핀 성분에 의한 것으로 설명된다. ${ }^{4)}$ 스핀에 의해 발생되는 다강체 인 경우 상온에서 두가지 강성이 다 보여진다고 알려져 왔으나, 재료 자체의 자연적인 특성보다는 다른 요인(화
학적 첨가물, 압력 및 변형 등의 효과)로 이러한 특성이 강화되는 현상도 보여지고 있다. 가장 활발하게 연구되 고 있는 단일상 다강체 물질인 $\mathrm{BiFeO}_{3}$ 인 경우 lone pair 메커니즘을 통해 자기-전기 결합을 특성을 설명하고 있 다. Lone pair 메커니즘은 $6 \mathrm{~s}$ 준위에 두 개의 전자를 가 진 $\mathrm{Bi}^{3+}$ 이온의 sterochemical activity에 의해 커다란 분극이 발생되며, $\mathrm{Fe}^{3+}$ 이온의 $3 \mathrm{~d}$ 준위의 전자로 인해 $\mathrm{Fe}^{3+}$ 이온간 초교환 상호작용이 일어나며, 이를 통해 반 강자성이 보여진다. 하지만 이러한 강유전성과 자성이 동시에 존재한다고 하여도 이것이 강한 자기-전기 결합 (magnetoelectric coupling)을 보장 하지 못하며, 이러 한 독립적인 다강체를 type I 이라 정의한다. 이와 달리 강유전성과 자성의 변이가 긴밀히 연결되어 있는 다강 체를 type II라 분류한다. ${ }^{5}$

최근 들어 자기-전기 다강성 재료는 특히 메모리 분 야로의 응용성에 관심을 가지고 많은 연구가 진행되 고 있다. 이는 기존의 메모리 소자의 대처 되는 연구 로서, 전기장에 방향에 따른 분극의 방향성을 변환 시 킬 수 있는 강유전성과 자기장의 방향에 따른 자성의 방향을 전환 시킬 수 있는 강자성의 특징을 동시에 적 용하여 디지털화가 가능하게 한다. 강유전체를 이용한 FeRAM(ferroelectric random access memories)에 서 보여지는 빠른 처리 속도(5ns) 와 높은 밀도(64MB) 
장점과 결정 구조의 깨짐이 없는 $\mathrm{MRAMs[magnaetic}$ random access memories]의 장점이 결합할 수 있게 된다. ${ }^{4,6)}$ 또한, 다강체인 경우 낮은 전류밀도를 가진 전 압의 pulse 신호로 비트(bit)를 쓰고 자기적(magnetic) 으로 비트를 읽기가 가능해진다. 이는 전류 발생에 따 른 열적 손실과 상대적으로 긴 축적(buildup) 시간을 피 할 수 있다. 이와 함께 분극과 자화 상태를 모두 이용한 4 비트 메모리 소자로서 활용 가능성도 함께 지니고 있 다. ${ }^{7}$ 따라서 이러한 다강체는 상대적으로 더 빠르고 더 효율적인 에너지 사용과 함께 집적도가 향상된 차세데 데이터 저장 메모리의 가능성을 보이고 있다.

이러한 응용 분야의 적용을 위해서는 다강체가 덩어 리(bulk) 또는 단결정보다는 박막(thin film) 형태가 보 다 적합하며, 2000 년대 이후 다강체에 대한 많은 연 구들이 박막 합성 및 증착하는 기술 개발 위주로 연구 되어 오고 있다. 이는 대부분의 단일상 다강체가 자연 계에서 거의 존재하지 않으며, 그에 따라 안정된 상으 로 합성도 힘들기 때문이다. 하지만, 이러한 평형상태 (equilibrium)에서 얻기 어려운 단일상 다강성을 다양 한 박막 성장 기술의 적용 및 새로운 박막 합성 기술을 통해 극복해 나가는 연구가 많이 진행되고 있으며, 이러 한 연구 중심에는 에피탁시(epitaxy)하게 고품질 박막 을 성장시키는 기술의 개발이 주요하게 적용되고 있다. 이와 함께 에피탁시한 박막 증착 시 사용되는 기판(예. $\mathrm{Si}, \mathrm{GaN}$, sapphire, $\mathrm{LaAlO}_{3}, \mathrm{MgO}$ 등) 및 증착 조건 등 에 의해 피할 수 없이 발생되는 변형(strain)도 필수적으 로 함께 고려해야 한다. 이는 결정 격자뿐만 아니라 오 비탈(orbital) 그리고 스핀(spin)과 결합(coupling)을 통 한 복잡하고 다양한 물리적 현상을 야기할 수 있다. 일 반적으로 자기-전기 단일상 다강성 박막 재료인 경우 다양한 가전자를 가지는 금속 양이온들의 조합이 가능 한 $\mathrm{ABO}_{3}$ 의 화학적 조성을 바탕으로 왜곡된 페로브스 카이트(perovskite) 구조를 가지고 있으며, 대표적으로 $\mathrm{BiFeO}_{3}, \mathrm{YMnO}_{3}, \mathrm{TbMnO}_{3}$, 그리고 $\mathrm{BiMnO}_{3}$ 등이 있다.

이러한 자기-전기 효과를 보여주는 다강성 물질에 대 한 연구는 오늘날 차세대 전자, 메모리뿐만 아니라 에너 지 수확 기술과 같은 새로운 응용 분야로의 접근과 함께
가장 중심이 되어 연구가 진행되고 있다. ${ }^{8)}$

\section{2. 본론}

오늘날까지 복합 산화물 관련 새로운 상 형성 방법 및 기술들에 대한 연구들은 많은 연구자들에 의해 발전 되어 오고 있다. 특히, 기존의 물질에 변형 엔지니어링 (strain-engineering) 적용 및 비평형 상태에서 존재하 는 새로운 상에 대한 박막 증착 기술의 발전을 통한 연 구가 활발히 진행되고 있다. ${ }^{9)}$ 이렇게 발전된 박막 증착 기술은 에피탁시한 복합 산화물 박막 성장을 용이하게 하며, 이는 새로운 단일상 다강체 물질의 개발에 기여할 뿐만 아니라, 벌크 형태의 단결정과는 달리 좀 더 대량 생산 체계에도 적합하다. 기본적으로 박막 증착은 펄스 레이저 증착법(pulsed laser deposition, PLD), 분자 빔 에피탁시 (molecular beam epitaxy, MBE), 스퍼터 링(sputtering)과 같은 다양한 최첨단 물리적 증착 기 술과 졸겔(sol-gel) 스핀 코팅(spin-coating) 및 금속 유기 화학 기상 증착(metal-organic chemical vapor deposition, MOCVD)과 같은 화학적 합성 방법으로 분 류된다.

지금까지 보고되어진 다강성 재료는 단결정과 박막 형태가 주를 이루고 있다. 대부분의 다강체는 단일상이 아닌 다성분계 산화물에서 보여지고 있다. 그 중 박막에 대한 연구는 최근 30 40년 사이 박막 증착 장비 발달 로 인해 더욱더 활발히 연구가 되어 오고 있다. 예를 들 어 대표적인 단일상 다강체인 $\mathrm{BiFeO}_{3}(\mathrm{BFO})$ 는 1960 년 대 단결정 형태로 광범위하게 조사되어 왔으나 낮은 결 정 품질과 높은 누설 전류, 그리고 낮은 잔류 분극 값을 보여줘 왔다. ${ }^{10-12)}$

하지만 2003년 Ramesh 교수가 이끄는 연구팀에서 $\mathrm{PLD}$ 방법을 통해 $\sim 55 \mu \mathrm{C} / \mathrm{cm}^{2}$ 의 큰 잔류 분극을 가지 는 고품질의 에피탁시 $\mathrm{BFO}$ 박막을 Science 지에 보고 된 이후 많은 연구들이 활발히 진행되고 있다. ${ }^{13)}$ 이는 자연상에 희박하게 존재했던 상온 다강체에 대한 연구 에 큰 발화점이 되었으며, 자기-전기 소자의 개발 가능 성을 높였다. 이 후에는 $\mathrm{BFO}$ 박막을 증착을 위해 $\mathrm{PLD}$ 


\section{특 집 ㅁㅃ 여홍구}

방법을 적용한 연구뿐만 아니라 $\mathrm{MBE}$, 스퍼터링과 같 은 다양한 최첨단 물리적 증착 기술과 $\mathrm{CSD}$ 및 $\mathrm{MOCVD}$ 와 같은 화학적 증착 기술을 활용한 연구도 함께 진행되 어 왔다. 기본적으로 이러한 박막 증착은 핵 생성 및 성 장 과정으로 이루어졌다. 일반적으로 박막 물질의 핵 생 성은 증착 입자(adatom)들이 기판 위에 안착한 후 이들 입자들이 모이거나 흩어지게 되는데, 이 중 모이는 입자 들이 일정한 크기 즉 임계 크기 이상으로 형성 될 때를 핵이 생성되게 된다. 안정된 cluster 형태의 핵이 형성 된 이 후, 그 주변부로 입자들이 쌓여 나가면서 점점 성 장을 하게 되며, 최종적으로 박막 형태로 만들어지게 된 다. 이러한 과정에 대한 이해와 함께, 증착 장치의 변수 (예, 증착 속도, 기판 온도, 내부 압력 등)를 제어가 이루 어지게 되면, 원하고자하는 특성을 지닌 박막 물질을 성 장 시킬 가능성이 증대된다. 이러한 증착 기술을 이용하 여 배향성(orientation)을 조절된 고품질 다강체 박막을 기판 위에 얻을 수 있을 뿐만 아니라, 벌크(bulk) 형태 로 존재가 힘든 비평형적(non-equilibrium)상을 변형 엔지니어링(strain-engineering)을 통해 새로운 형태 의 다강체 박막 물질의 개발도 가능하게 된다. 벌크 형 태의 단일상 산화물 다강체는 일반적으로 깨지기 쉬우 며 소성 변형 전에 가할 수 있는 인장 변형이 $0.1 \%$ 이하 의 제한적인 고유의 기계적 특성을 가지고 있다. 그러나 같은 물질을 박막으로 성장 시키는 경우, 기판 및 증착 조건에 따라 커다란 이축의 변형(biaxial strain)이 인 가 된 상태로 성장 시킬 수 있다. 즉 박막에 큰 변형력이 가해진 상태에서 불규칙성(disorder)으로부터 자유로운 상으로 박막 성장이 가능하다. 이는 변형 엔지니어링을 통한 새로운 다강체 연구를 가능하게 한다. 예를 들어 $\mathrm{EuTiO}_{3}$ 물질인 경우 응력에 인가됨에 따라 상의 변화와 함께 특성이 바뀌는 현상을 보여주고 있다(Fig. 2). 응 력이 인가되지 않은 평형 상태에서는 강유전성과 강자 성이 보이지 않는 반면 커다란 biaxial 응력을 인가 시 강한 강자성과 강유전성을 가짐을 보고하였다. ${ }^{14)}$

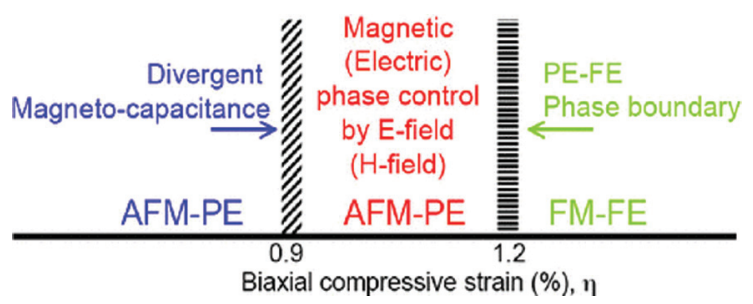

Fig. 2. $\mathrm{EUTiO}_{3}$ : Compressive epitaxial strain ( $\eta$ ) phase diagram. Adapted from Fennie et al. Phys. Rev. Lett. 2006;97:267602, with permission of Elsevier [14].

\section{1 다강체 박막의 물리적 증착 방법}

\section{Pulsed laser ablation (PLD)}

PLD 방법은 레이저를 타켓에 주사하여 기화되는 종 (species)들이 기판에 증착되는 간단한 형태의 물리적인 증착 방법으로 새로운 물질 또는 에피탁시한 박막 성장 시킬 때 많이 사용되는 방법이다. 특히 박막 성장 과정 중 준평형 또는 평형(equilibrium)으로부터 멀리 있는 물질의 성장이 가능한 증착 방법이며, 다성분으로 이루 어진 복합물의 화학양론적비 조절 하는데 용이하다. 기 본적으로 $\mathrm{PLD}$ 증착에 필요한 구성은 크게 펌프가 장착 된 진공 용기(chamber), 타겟 홀더 및 기판 히터와 함 께 광학 렌즈 등으로 구성되어 있으며, Fig. 3(a)에 개략 적으로 나와 있다. ${ }^{15)}$ 일반적으로 $\mathrm{PLD}$ 을 통한 산화물 박 막 성장을 위해 산소, 오존 또는 산소 원자의 부분 압력 을 통해 제어가 가능하며, 이와 함께 증착 될 기판의 온 도를 제어함으로 넓은 범위의 열역학적 조건하에 박막 증착이 가능하다. 이러한 단순한 구조로 되어 있는 PLD 장치는 다른 증착 장치와 달리 조리개, 감쇠기, 거울 및 렌즈를 포함하는 광학 장치가 장착되어 있다. 주사된 레 이저(laser) 빔이 렌즈를 통해 용기(chamber) 내에 적 절한 에너지로 집중되어 타켓(target)을 절삭(ablation) 하게 하며, 이렇게 증발된 아원자(adatom)들이 기판에 증착 하게 된다. $\mathrm{PLD}$ 는 여러 대상의 증착 재료를 간단 하게 교체가 가능하며, 이는 광범위한 재료를 탐색 및 원형(prototype) 박막을 얻기에 용이하다. 이러한 장치 는 자연상에 잘 존재하지 않은 상을 개발하기 위한 연구 로 시작하기에 적합하여, 대학교내 소규모의 연구 그룹 
에서 단일상 다강체 박막을 위해 활용되고 있다. ${ }^{16-18)}$ 최 근에 PLD 하드웨어에 많은 발전이 있었으며, $\mathrm{MBE}$ 에 필적한 기능으로 박막의 증착 층을 정밀하게 제어가 가 능하게 되었다. 특히 실시간으로 증착되는 박막의 성장 과정을 모니터링 할 수 있는 RHEED(reflection highenergy electron diffraction)와 같은 시스템으로 인해 보다 더 고품질의 다강체 박막을 개발하는데 활용하고 있다. ${ }^{18)}$ 또한 이원소 이상의 산화물 재료를 순차적으로 그리고 layer-by-layer 성장을 가능하게 하였다. 일례 로 $\mathrm{Bi}\left(\mathrm{Fe}_{1-\mathrm{x}} \mathrm{Cr}_{\mathrm{x}}\right) \mathrm{O}_{3}$ 와 같은 다강체를 만드는 데 여러 타겟 에서 합금 형성을 가능하게 하는 자동화 시스템이 사용 되었다. ${ }^{19-21)}$

\section{분자 빔 에피탁시 (molecular beam epitaxy, MBE)}

원자층 단위에 초정밀 박막 성장의 제어가 가능한 분 자 빔 에피탁시 증착 기술은 1980년대 고온초전도체에 대한 연구와 함께 고품질 복합 산화물 박막을 중심으로 연구가 진행되어 온 이 후 십 수년간 수많은 물질의 성 장에 대한 장치로 발전되어 왔다. ${ }^{22)} \mathrm{PLD}$ 와 달리 $\mathrm{MBE}$ 는 낮은 에너지 $(1 \mathrm{eV})$ 을 가지고 증착하고자 하는 조성 의 열적 원자 또는 분자 빔(molecular beam)들을 주사 하여 이들을 증착하는 방식으로 단층 수준(monolayer level)의 박막 두께 조절이 가능하며 초고진공 $\left(\sim 10^{-6}\right.$ Torr 이하) 용기 내에서 에피탁시한 박막 성장에 용이 한 증착 방법이다. 이러한 고품질의 에피탁시 박막 증 착과 함께 단위 격자 크기 박막 두께를 정밀하게 제어하 기 위해서는 실시간으로 성장층에 대한 관찰이 필수적 이며, 이를 위해 일반적으로 RHEED이 장착하여 사용 된다. 다성분계의 복합 산화물 증착 시 금속 양이온들은 각각의 금속 원료(source)을 열적으로 활성화 시킨 분자 빔과 산소 또는 질소와 같은 기체 분자와의 반응을 통해 산화물 또는 질화물 성장시킬 수 있으며, 이를 반응성 (reactive) $\mathrm{MBE}$ 라고 한다. 이러한 증착 기술 뿐만 아니 라 휘발성 금속 유기 원료를 이용한 금속-유기(metalorganic) $\mathrm{MBE}$ 증착법 개발되어 점점 다양한 복합 산화 물 성장에 적용되고 있다. ${ }^{23,24)}$ 비록 $\mathrm{PLD}$ 와 $\mathrm{MBE}$ 는 결함 이 없는 고품질의 산화물 박막이 증착이 가능하지만 초
기 장비 구축 비용이 비싸, 이로 인한 연구 접근성 제한 과 함께 대면적의 기판에 증착에 상대적으로 어려움을 가지고 있다. 하지만 이러한 제한된 요소에도 불구하고 초고진공 용기 내에서 이루어지는 원자 단위의 두께로 제어가 되는 시스템은 차세대 재료 분야에 큰 영향력을 미칠 것이다.

\section{마그네트론 스퍼터링(magnetron-sputtering)}

1970년대 기본적인 형태의 마크네트론 스퍼터링이 개발된 이후 멀티(multi) 타켓을 이용한 스퍼터링과 같 은 다양한 형태의 스퍼터링이 오늘날까지 개발 되고 있 다. 마그네트론 스퍼터링은 일반적으로 플라즈마(glow discharge plasma) 내 방전된 활동성(energetic)이 있 는 이온들이 타켓(또는 음극)을 가격하여 방출된 운동성 을 가지는 물질들이 기판에 증착되는 공정을 이야기 한 다. 그리고 이러한 공정을 통해 반도체, 유전체, 절연체 자기 및 초전도 산화물과 같은 다양한 재료들을 증착 하 기 위해 사용될 뿐만 아니라 촉매, 보호용 코팅 등의 목 적으로도 이용되고 있다. ${ }^{25)}$ 비록 $\mathrm{PLD}$ 및 $\mathrm{MBE}$ 와 같은 증착법에 비해 상대적으로 고품질의 복합 산화물 박막 을 증착하기는 어려우나, 대면적의 기판과 빠른 증착 속 도로 인한 대규모 생산에 이용되는 증착 기술이다.

기본적으로 산화물 또는 절연체 박막 성장을 위해 산 화물 타켓을 이용한 $r f$-magnetron 방식과 금속 타켓에 반응성 기체(예. 산소, 질소)을 이용한 $\mathrm{DC}$ 스퍼터링 방 식으로 박막 성장이 가능하다. ${ }^{26-29)}$

$r f$ 방식을 통한 산화물 박막 증착 시 용기 내에 산소 또는 산소/아르곤 $\left(\mathrm{O}_{2} / \mathrm{Ar}\right)$ 반응성 기체의 분압을 통해 타켓에서 튀어나온 타켓 입자의 물리적 에너지를 조절 을 하게 된다. 이와 함께 기판 온도 및 바이어스 전압 그 리고 기판과 타켓 간의 거리 등의 조정을 통해 표면 구 조 및 결함 밀도에 영향을 받게 되며, 따라서 이들 변수 의 최적화 과정을 거쳐야만 고품질 박막을 얻을 수 있 다. ${ }^{30)}$ 여기서 산소 또는 $\mathrm{Ar} / \mathrm{O}_{2}$ 혼합 기체와 같은 반응성 기체는 종종 산화물 박막의 화학양론적 조성을 조절하 기 위한 중요한 변수가 된다. 복합 산화물인 경우 각각 의 원소들마다 기판에 가해지는 운동성 및 반응성의 차 


\section{특 집 ㅁㅃ 여홍구}
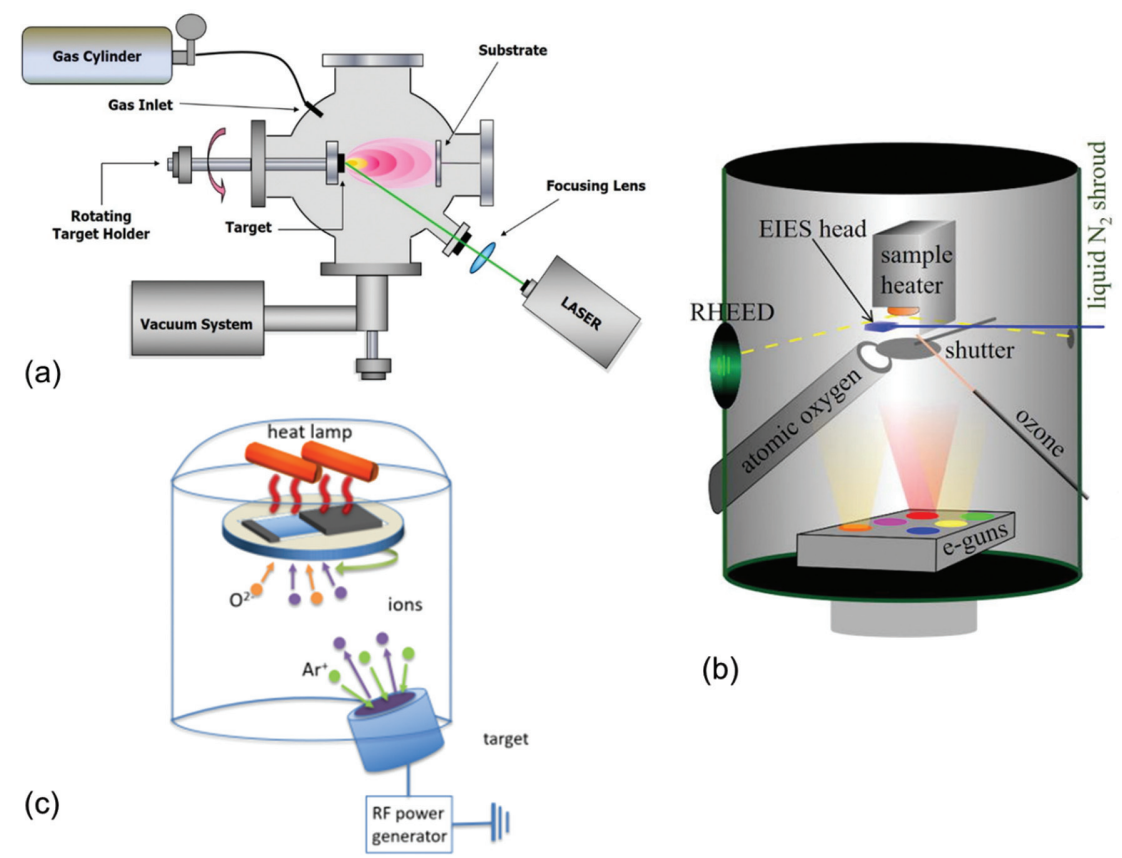

(b)

Fig. 3. (a) Experimental set-up for Pulsed Laser Deposition (PLD) experiments in vacuum or in gas pressure. Source from Bonis et al. Coatings 2021;10:501 [15]. (b) Chamber setup for molecular beam epitaxy. Reproduced from Krockenberger et al. J. Appl. Phys. 2018;124:073905 [34]. (c) Schematic view of high temperature if-sputtering system. Adapted from Yeo et al. Adv. Fuct. Mat. 2018;28:1801327, with permission of Wiley [35].

이로 인해 증착하는 상의 화학양론성을 제어하는데 어 려움에 직면 할 가능성이 많다. ${ }^{31)}$ 다강자체 또는 강유전 복합 산화물 박막 성장을 위해 멀티 금속 타켓을 활용한 (multi-ion-beam reactive sputtering) 방법도 연구 되어 오고 있다. 이러한 멀티 타켓을 활용한 반응성 스 퍼터법은 박막 기판 전 영역에 균일한 상으로 증착이 중 요하며, 일반적으로 이를 위해 기판을 회전 시켜 개선해 나가고 있으나, 여전히 기판 전 영역에 화학양론성을 균 일하게 성장시키는 것은 스퍼터링 증착에서 어려운 과 제로 남겨져 있다. 오늘날까지 스퍼터링을 통해 다양한 다강성 박막 재료들이 증착되어 왔으며 대표적인 예로 $\mathrm{YMnO}_{3}$ 와 $\mathrm{BiFeO}_{3}$ 등이 있다. ${ }^{32,33)}$

\section{화학 증착법 (Chemical deposition methods)}

복합 산화물 다강체 박막 증착에 관한 접근 방법으 로 물리적인 증착 방법과 함께 다양한 화학적 증착 방법 을 통한 연구들도 활발히 진행되고 있다. 그 중 금속-
유기 화학 기상 증착(MOCVD) 기술은 기본적으로 균일 한 두께의 박막 증착과 함께, 기체상의 조성을 통한 박 막 화학량론성 제어와 재현성이 좋으며, 비교적 높은 증 착 속도를 가지고 있다. MOCVD의 기본 원리는 원하 는 증착하고자 하는 원소가 포함된 기체 상의 유기 분 자 전구체(organic molecular precursor)들 간의 화학 반응을 이용하여 박막을 성장시키는 방법이다. 이를 위 해 불활성 기체를 액체 전구체를 통과 시켜 기체와 같 이 증발되는 분자를 반응 용기에 흘려 보내어 이렇게 날아간 기체 분자들이 고온에 기판에 도달하여 끊어지 면서 원하는 물질만 표면에 증착되는 방식이다. 이러 한 증착 방법은 산화물 재료 특히 높은 원자 번호(상온 에서 제한된 증기압을 가짐)가 포함된 재료인 경우 제 한적이나, 근래에 새로운 금속-유기물 전구체(metalorganic precursor)의 출현으로 산화물 다강성 물질에 대한 큰 가능성을 제공하였다. 대표적인 예로 $\mathrm{BiFeO}_{3}$ 의 개발에서 특히 중요하다. ${ }^{36)}$ 이러한 MOCVD 증착법은 


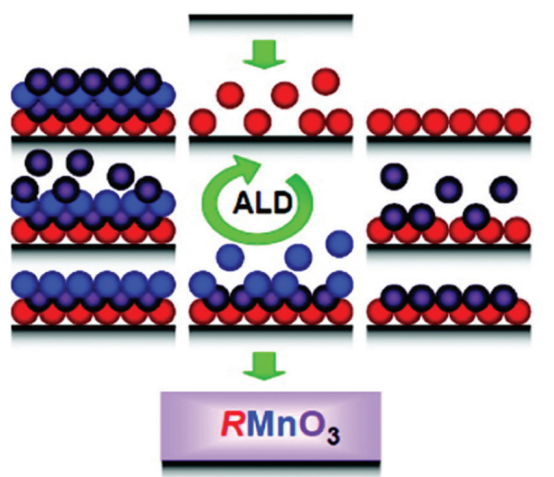

(a)

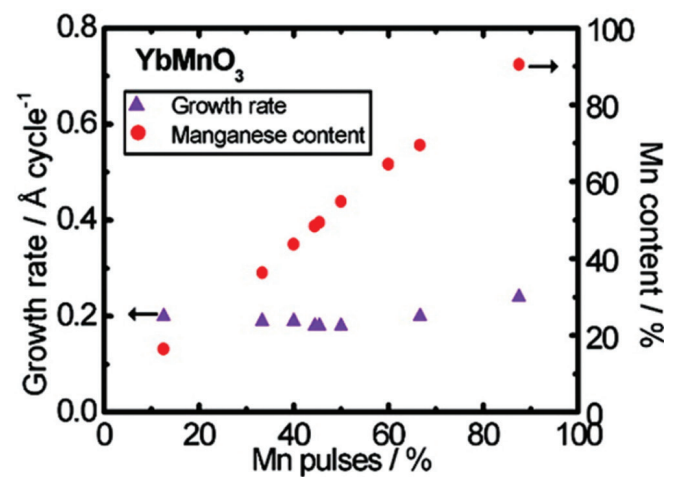

(b)

Fig. 4. (a) ALD processing steps and (b) Effect of the precursor pulsing ratio on the actual Mn content $(\bullet)$ and the growth-percycle (GPC) value $(\boldsymbol{\Delta})$ of $\mathrm{R}_{\mathrm{x}} \mathrm{Mn}_{\mathrm{y}} \mathrm{O}_{3}(\mathrm{R}=\mathrm{Yb})$ films at deposition temperature of $275^{\circ} \mathrm{C}$. Adapted from Uusi-Esko et al. Chem. Mater. 2011;23:1835-1840, with permission of American Chemical Society [39].

공정 조건, 반응 용기 구성, 전구체의 전달 방법 등에 따 라 저압(low-pressure) MOCVD, 대기압(atmospheric pressure) MOCVD, 수평/수직 MOVCD 및 플라즈마 강화(plasma-enhanced) MOCVD 등이 있다. ${ }^{37)}$

또 다른 증착법으로는 화학적 용액 증착법 (chemical solution deposition, CSD)이 있으며, 졸-겔(sol-gel) 을 이용한 증착 방법이 있다. 이들 방법의 증착 과정은 크게 증착하고자 물질의 전구체 용액을 합성 후 스핀 코 팅 및 dip-coating 방법으로 기판에 증착 후 저온 열처 리를 통해 비정질 박막을 형성한 후 원하는 두께가 될 때까지 앞의 코팅 공정을 반복을 하게 된다. 이 후 고온 의 열처리 과정을 통해 고밀도화 및 결정화를 이루어지 게 한다. 이러한 $\mathrm{CSD}$ 증착법은 매우 다양하며, 초기 장 치 구축에 비용이 저렴하고, 균일한 두께와 화학양론성 의 손쉬운 제어 등의 장점을 가지고 있다. 하지만 이러 한 용액을 통한 증착 방법은 에피탁시한 박막 및 아주 얇은 두께를 가진 초박막(ultra-thin film)을 얻는데 한 계를 가지고 있다. 또한, 화학 기상 증착법과는 달리 연 속적인 성장이 일어나지 않기에 박막 표면과 박막 내부 간의 조성의 차이가 발생할 수 있다.

원자층 증착법 (atomic layer deposition, ALD)을 활 용한 산화물 박막에 관한 연구는 최근 들어 가장 활발히 연구되고 있다. 기상(vapor)의 전구체 분자와 기판 표 면간의 제한된 반응으로 증착되는 방법인 ALD 경우 이
들 전구체의 기판 도달 순서를 제어 할 수 있어 보다 더 정확하게 원하는 상을 성장이 가능하게 한다. 최근 몇몇 문헌에서 ALD 을 통한 산화물 다강체 박막 개발에 대해 보고된 바가 있다. ${ }^{38)}$ 예를 들어 2011년에 Kusi-Esko 와 M. Karppine에 의해 R(td) $)_{3}, \mathrm{Mn}(\mathrm{thd})_{3}$ 및 오존을 전 구체로 이용하여 사방정계 및 육방정계 희토류 망간염 (rare-earth manganite, $\mathrm{RMnO}_{3}$ )을 $\mathrm{ALD}$ 증착법을 통 해 $\mathrm{LaAlO}_{3}$ 기판 위에 성장시켰다. ${ }^{39)}$ 특히 각각의 $\mathrm{RMnO}_{3}$ ( $\mathrm{R}=\mathrm{La}$ to $\mathrm{Lu}$ ) 박막을 $275^{\circ} \mathrm{C}$ 에서 전구체의 펄스(pulse) 와 퍼지(purging) 시간 조절을 통해 R/Mn 화학양론비 가 우수하게 조절된 연구 결과를 보고하였다(Fig. 4). ${ }^{39)}$

\section{2 단일상 다강체 박막}

다강성을 보여지는 재료에 대한 알고리즘이 많이 있 음에도 불구하고 현재까지 합성된 대부분의 단일상 다 강체는 육방정계 망간염(hexagonal manganites)과 $\mathrm{Bi}$ 및 $\mathrm{Pb}$ 기판으로한 페로브스카이트 구조를 가진 재 료가 대부분이다. 하지만 증착 기술은 발전과 함께 새 로운 단일상 다강성 박막 연구 개발은 계속 될 것으 로 사료된다. 본 원고에서는 지금까지 보고되어진 단 일상 박막 다강체를 우선 알아보고자 한다. 다강체 망 간염 중 가장 먼저 보고된 육방정계 $\mathrm{YMnO}_{3}(\mathrm{YMO})$ 물 질은 1960 년대 반강자성과 강유전적 특성이 서로 독립 적으로 작용하는 type-I 형태로 보고되어 왔다. 1996 


\section{특 집 ㅁㅃ 여홍구}

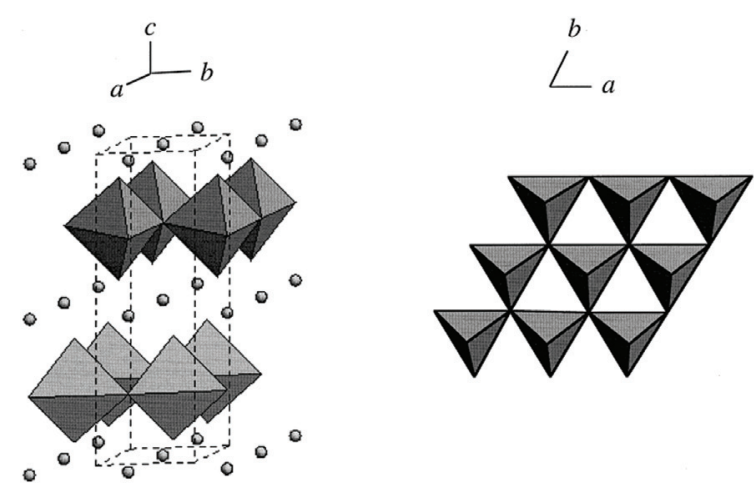

(a)
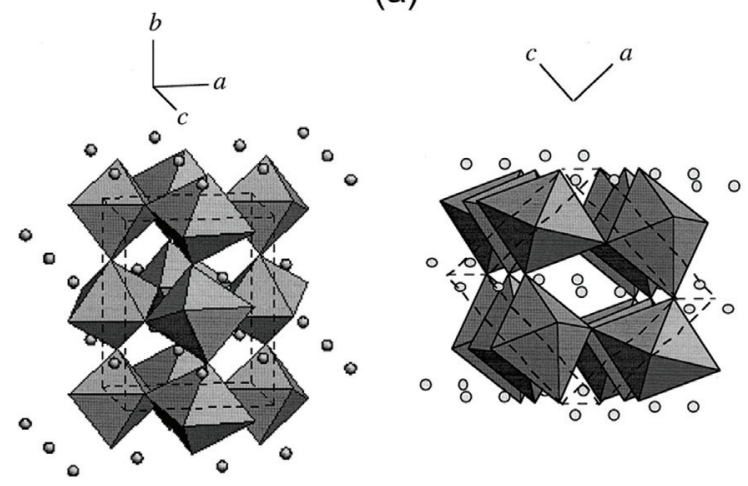

(b)

Fig. 5. (a) Polyhedral representation of the structure of the hexagonal from of $\mathrm{YMnO}_{3}$. The spheres represents the $\mathrm{Y}^{3+}$ cation while the $\mathrm{Mn}^{3+}$ cations reside near the center of the 5-coordination polyhedral and $\mathrm{O}^{2-}$ anions at the apexes of the polyhedral. (b) Polyhedral representation of the structure of the hexagonal from of $\mathrm{YMnO}_{3}$. The spheres represents the $\mathrm{Y}^{3+}$ cation while the $\mathrm{Mn}^{3+}$ cations reside near the center of the 6 -coordination polyhedral and $\mathrm{O}^{2-}$ anions at the apexes of the polyhedral. Adapted from Salvador et al. Chem. Mater. 1998;23:1835-1840, with permission of American Chemical Society [40].

년 $r f$ 스퍼터링을 통해 처음으로 $(0001) \mathrm{ZnO} /(0001)$ sapphire 기판위에 (0001) 배향된 에피탁시(epiaxial) 박막을 얻을 수 있었다. ${ }^{32)}$ 스퍼터링을 통한 화학양론적 $\mathrm{YMO}$ 박막을 얻기 위해 다양한 $\mathrm{Y} / \mathrm{Mn}$ 조성 비를 가진 타켓을 통해 최적화 시켰으며, (111) $\mathrm{Pt} /(111) \mathrm{MgO}$ 기판 에서 다결정(polycrystalline) 박막을 성장됨을 보여주 었다. hexagonal YMO 재료는 고온 $\left(\sim 900^{\circ} \mathrm{C}\right)$ 에서 강유 전상 변이 온도를 가지는 반면, 낮은 온도 반강자성 변
이 온도를 가진다. 이 후 다양한 기판 (i.e. (001) $\mathrm{SrTiO}_{3}$, $\mathrm{NaGaO}_{3}$ )을 이용하여 준안정한 사방정계 페로브스카이 트 상을 얻을 수 있었다. ${ }^{40)}$

이러한 연구는 에피탁시 변형(epitaxy strain)을 통 해 사방정계와 육방정계 $\mathrm{YMO}$ 상 간의 구조적 특성 및 성질 조절이 가능함을 시사한다(Fig. 5). 이 후 PLD 방 법을 통해 (111)Pt/(0001)sapphire 기판 위에 증착된 $\mathrm{YMnO}_{3}$ 박막에서는 비록 단결정에서 볼 수 있는 강유전 분극 특성에 비해 낮은 잔류 분극 $\left(\mathrm{P}_{\mathrm{r}}=1.7 \mu \mathrm{C} / \mathrm{cm}^{2}\right)$ 값을 보였으나, 강유전성 게이트 전계 효과 트랜지스터로서 가능성은 보였다(Fig. 6). ${ }^{411}$ 또한 (111) $\mathrm{SrTiO}_{3}$ 기판 위에 증착된 (0001) 에피탁시 $\mathrm{YMnO}_{3}$ 박막에서는 반강자성 과 전기 분극의 공존과 함께 Fig. 7에서 보여지는 것처 럼 낮은 온도에서 exchange bias가 관찰되었다. ${ }^{42)}$

이외에도 $(001) \mathrm{Si}^{32,43)} \mathrm{Y}$-안정화된 $(111) \mathrm{ZrO}_{2}$ 를 ${ }^{44)}$ 포 함한 여러 산화물 기판 위에 $\mathrm{YMO}$ 박막이 증착되었다. 이뿐만 아니라 off-axis magnetron sputtering 방법 을 통해 격자상수가 $\mathrm{YMnO}_{3}$ 물질의 절반인 육방정계 구 조를 가진 $\mathrm{GaN}$ 기판 위에 성장이 되었다. ${ }^{45)}$ 분자 빔 에 피탁시 $(\mathrm{MBE})$ 증착법을 통해서는 $\mathrm{n}$-type (111) $\mathrm{Si}$ 기 판 위에 $\mathrm{Y}_{2} \mathrm{O}_{3}$ 버퍼층(buffer layer)을 $\mathrm{MBE}$ 로 증착 후 $\mathrm{YMO}$ 박막을 (0001) 방향으로 에피탁시하게 성장 시켰 으며, 이를 통해 강유전성만을 확인하였다. ${ }^{46)}$

그 밖에 화학적 증착 방법을 통한 다강체 박막 연구들 도 함께 진행되고 있으며, 알콕시기(alkoxy group) 바 탕의 전구체를 이용한 CSD 방법을 통해 $\mathrm{Pt} / \mathrm{TiO}_{\mathrm{x}} / \mathrm{SiO}_{2} /$ $\mathrm{Si}$ 기판 위에 c축으로 배향된 150 200nm 두께의 YMO 박막을 성장 시켰으며, 이를 통해 강유전성을 확인하였 다. ${ }^{43)}$ 금속-유기 화학 기상 증착을 통해 실리콘 기판 위에 성장시킨 $\mathrm{YMO}$ 박막에서도 스퍼터링으로 증착한 $\mathrm{YMO}$ 박막과 유사한 잔류 분극 $\left(\mathrm{P}_{\mathrm{r}} \sim 2 \mu \mathrm{C} / \mathrm{cm}^{2}\right)$ 과 유전 상수 $(\varepsilon \sim 20)$ 을 보여 주었다. $\left.{ }^{47}\right)$

$\mathrm{Bi}$ 계를 바탕으로 한 페로브스카이트 구조를 가지는 다강성 재료 중 $\mathrm{BiFeO}_{3}(\mathrm{BFO})$ 는 가장 많이 연구되고 있 는 물질로서 지금까지 보고된 바에 따르면 $\mathrm{BFO}$ 는 실온 에서 높은 분극을 지닌 강유전성과 반강자성을 지닌 유 일한 물질이다. 또한 높은 Curie 온도 (1143K)와 높은 


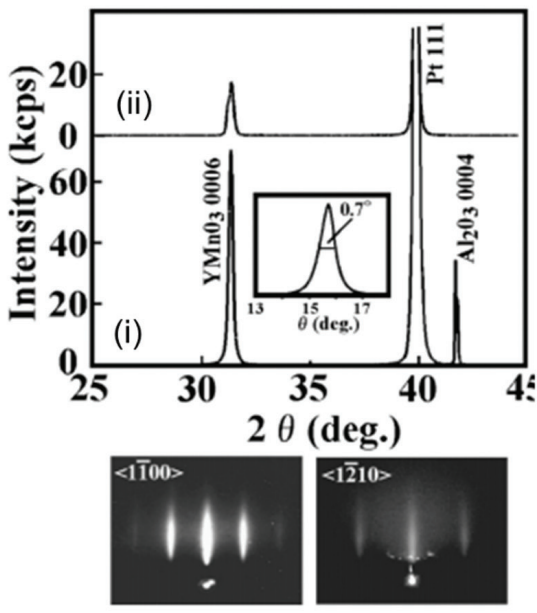

(a)

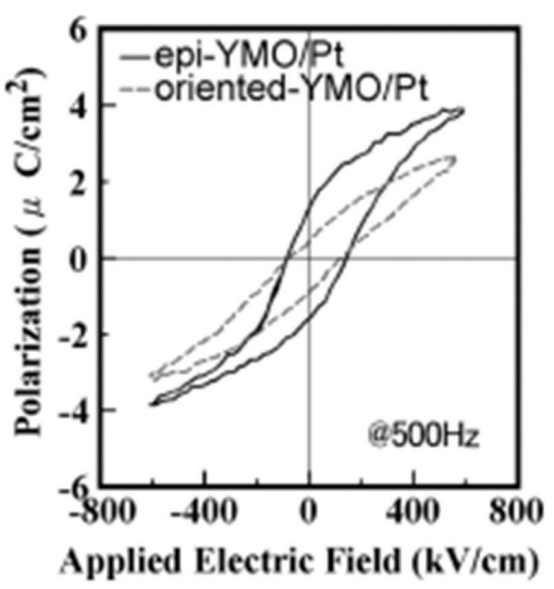

(b)

Fig. 6. (a) XRD patterns of (i)the epi-YMO/Pt and (ii)the oriented-YMO/Pt. and RHEED patterns of the epi-YMO/Pt. (b) P-E hysteresis of the epi-YMO/Pt and the oriented-YMO/Pt. Adapted from Ito et al. J. Appl. Phys. 2003;93:5563-5567 with permission of American Institute of Physics [41].

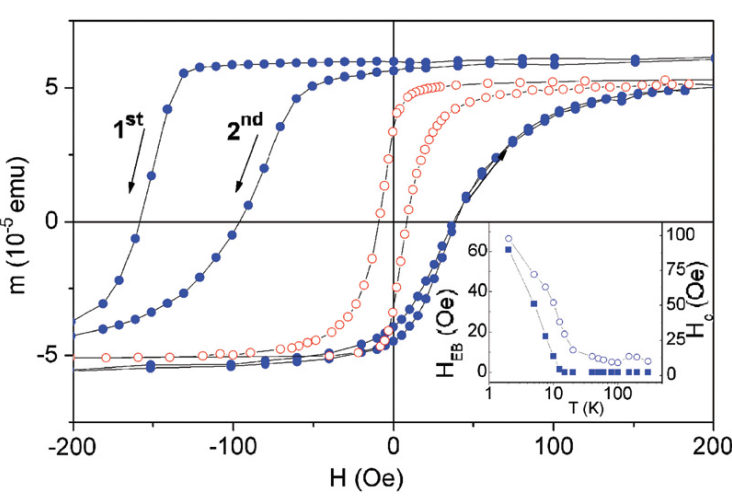

Fig. 7. Magnetization loops vs applied magnetic field, measured at $100 \mathrm{~K}$ (open symbols) and $2 \mathrm{~K}$ (close symbols), after cooling the sample from $150 \mathrm{~K}$ in a field of $3 \mathrm{kOe}$. Two consecutive loops recorded at $2 \mathrm{~K}$ are displayed. Inset: Temperature dependence of the exchange bias (closed squares) and the coercivity (open circles) fields. Adapted from Marti et al. Appl. Phys. Lett. 2006;89:032510 with permission of American Institute of Physics [42].

Néel 온도(643K)을 가지고 있다. ${ }^{48)} \mathrm{BFO}$ 결정 구조는 두개의 왜곡된 페로브스카이트가 pseudocubic의 [111] 방향 즉 대각선으로 연결되어 있는 구조를 가지고 있다. 강유전성 분극은 Fig. 8에서 볼 수 있듯이 $\mathrm{FeO}_{6}$ 팔면체 에 비해 $\mathrm{Bi}$ 이온이 크게 변위된 결과로서 이러한 $\mathrm{BFO}$

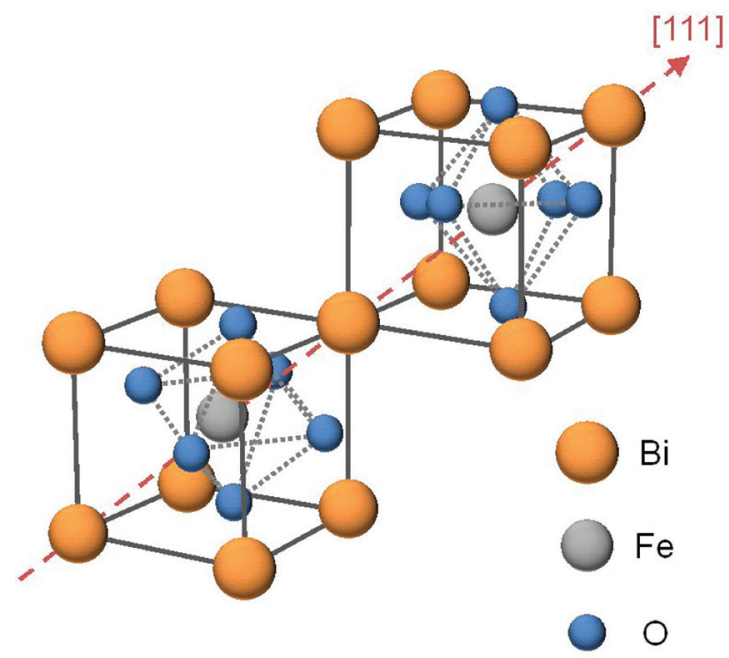

Fig. 8. Schematic view of the R3c structure built up from two cubic perovskite $\mathrm{BiFeO}_{3}$ unit cells. The cations are displaced along the [111] direction relative to the anions, and the oxygen octahedral rotate with alternating sense around the [111] axis. Source from DOl: 10.5772/54908.

는 [111] 방향으로 자발 분극 나타내는 것으로 측정되며 space group은 능면체 R3c에 속한다.

초기에 보고된 벌크 형태의 $\mathrm{BFO}$ 시편에서는 자발 분 극에서는 상대적으로 작은 값 $\left(\sim 6.1 \mu \mathrm{C} / \mathrm{cm}^{2}\right)$ 값을 가졌 으나, 이 후 flux 방법으로 성장시킨 단결정 $\mathrm{BFO}$ 에서는 


\section{특 집 뜨여옹구}
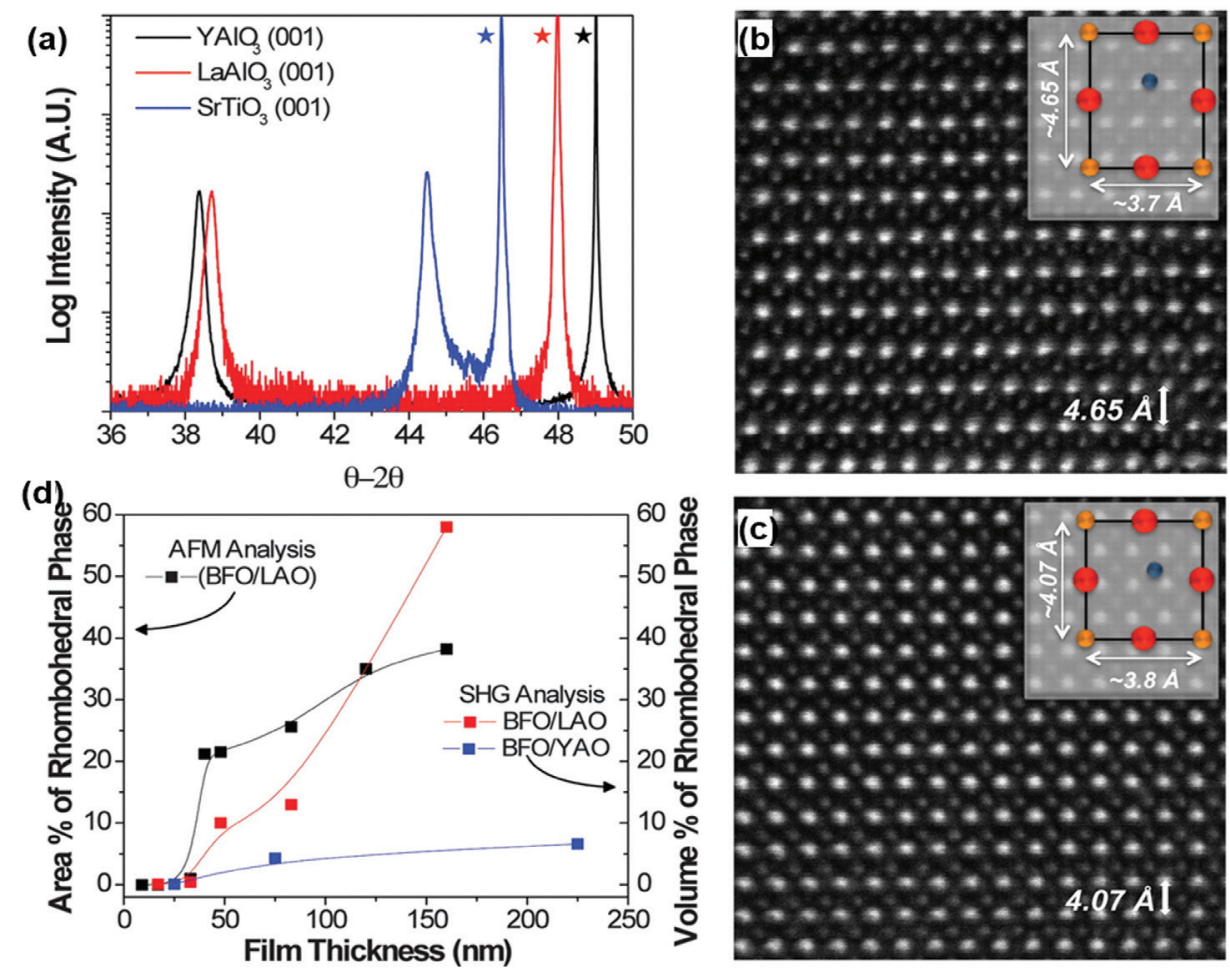

Fig. 9. (a) X-ray diffraction of the pseudocubic 002-diffraction peak of BFO/STO (001), BFO/LAO(001), and BFO/YAO(110) shows the presence of a long-axis T phase on both LAO and YAO substrates. Substrate peaks are marked with a star. (b and c) Atomic resolution STEM images of the T phase and the R phase, respectively. Insets show schematic illustration of the unit cell. (d) The evolution of the structure with thickness, including the area fraction (left axis) and the volume fraction of the R phase. Adapted from Zeches et al. Science 2009;326:977-980 with permission of The American Association for the Advancement of Science [54].

[111] 방향에 따라 휠씬 큰 자발 분극 값 $\left(\sim 90 \mu \mathrm{C} / \mathrm{cm}^{2}\right)$ 을 보여주었다. ${ }^{49)}$ 이는 이전 시료가 벌크 형태의 시료로 서 불순물 존재로 인한 것으로 사료된다.

박막 형태로 이루어진 연구에서는, 2003년에 PLD 방 법으로 증착된 에피탁시한 $\mathrm{BFO}$ 박막의 성장과 특성에 대한 연구 ${ }^{13)}$ 발표 이 후 십수년간 걸쳐 에피탁시하게 성 장시킨 박막의 상 안정성과 전자적 특성을 제어하는 방 향으로 연구가 진행되고 있다. 이와 함께, 큰 자발 분극 과 변형된 $\mathrm{BFO}$ 간의 관련 특성 연구들도 많이 보고되고 있다. 특히 변형된 에피탁시 $\mathrm{BiFeO}_{3}$ 의 박막은 $3.71 \AA$ 부 터 $4.01 \AA$ 범위의 격자 상수를 가지는 다양한 페로브스 카이트 산화물 기판 뿐만 아니라 $\mathrm{Si}$ 및 $\mathrm{GaN}$ 반도체 기 판에서도 증착된 연구가 보고되고 있다. 이로 인해 발 생된 박막의 변형률 변화는 $\mathrm{BFO}$ 의 domain 구조를 제
어할 수 있게 할 뿐만 아니라, 자화의 방향을 변화 시킬 수 있었다. ${ }^{50)}$ 예를 들어 상대적으로 격자 길이가 (111) $\mathrm{SrTiO}_{3}$ 기판에 증착 시 $\mathrm{BFO}$ 박막에 압축 변형이 발생 하게 되면 이로 인해 열역학적으로 평형한 8개의 분극 이 4 개의 분극 방향만을 선호하게 된다. ${ }^{51)}$ 또한, 박막 증 착 공정 요소 중 증착 속도에 따라 $\mathrm{BFO}$ 박막의 도메인 구조(예. stripe-like, mosaic-like) 변화를 가져왔으 며, 이에 따라 domain wall의 밀도의 변화도 함께 보여 주었다. 이러한 특정 형태의 domain wall로 인해서 강 자성 금속과 $\mathrm{BFO}$ 간의 교환 바이어스(exchange bias) 와 전체 자기 모멘트(moment)에 영향을 받게 된다. ${ }^{52)}$ 또한, (001) 방향으로 배향된 능면정(rhombohedral) 박 막에서는 $\{100\}$ 또는 $\{101\}$ domain boundary가 가지는 도메인 패턴이 존재하게 되면, 이러한 경우에는 stripe 

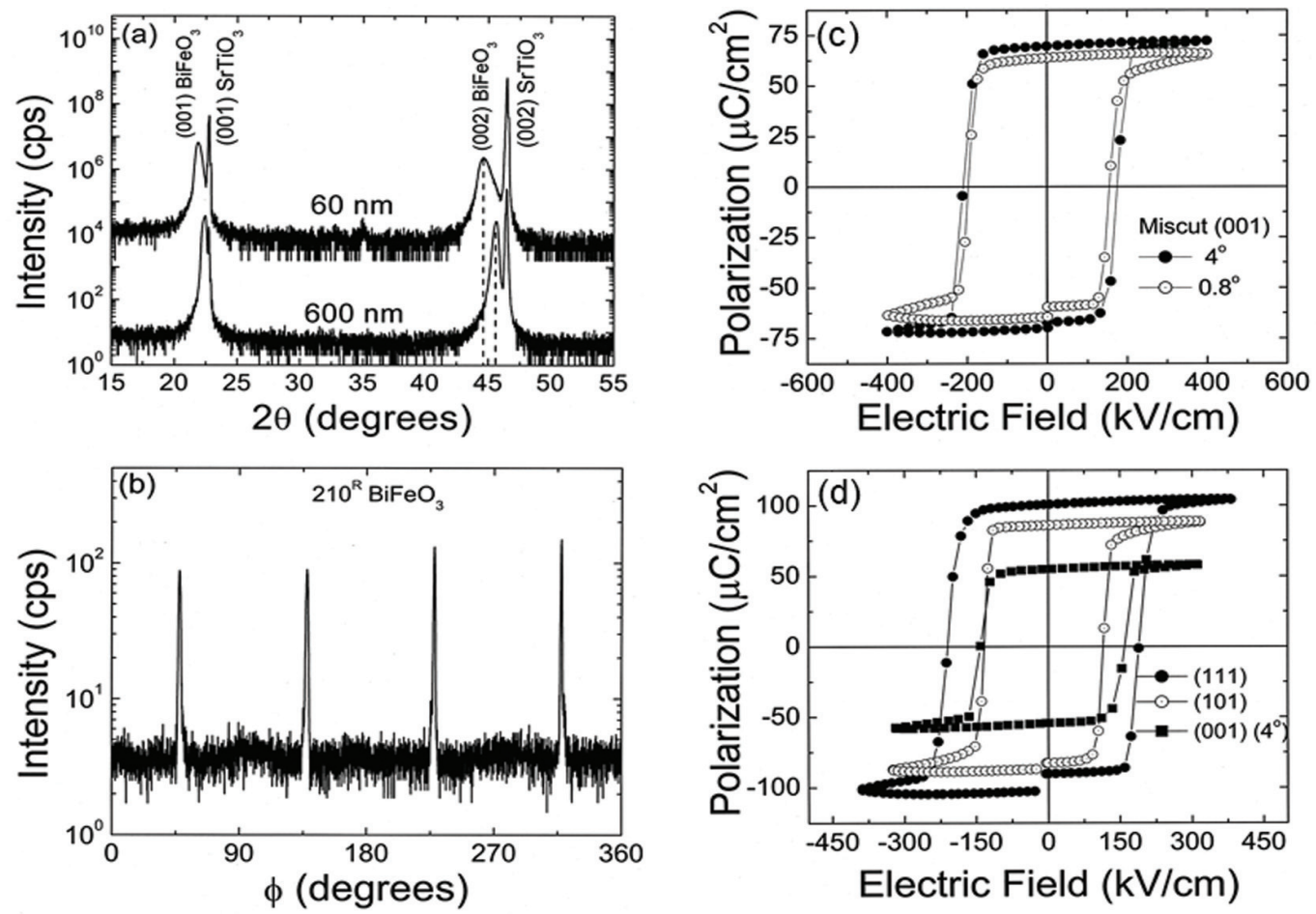

Fig. 10. X-ray diffraction $\theta-2 \theta$ scans for 60 and $600 \mathrm{~nm} \mathrm{BiFeO}_{3}$ thin films on (001) $\mathrm{SrTiO}_{3}$. (b) Off-axis azimuthal $\varphi$ scan of $210 \mathrm{R}$ rhombohedral $\mathrm{BiFeO}_{3}$ reflections. (c) $\mathrm{P}-\mathrm{E}$ hysteresis loops of $200 \mathrm{~nm} \mathrm{BiFeO}_{3}$ films on $0.8^{\circ}$ and 4 miscut $(001) \mathrm{SrTiO}_{3}$. (d) Hysteresis loops of 600nm thick (001), (101), and (111) oriented $\mathrm{BiFeO}_{3}$ films. The hysteresis loops were measured on capacitors with top electrode diameter of 200um. Adapted from Das et al. Appl. Phys. Lett. 2006;88:242904 with permission of American Institute of Physics [33].

형태의 패턴이 이론적으로 예측된다. ${ }^{53)} 2009$ 년도에는 $\mathrm{MBE}$ 방법으로 증착한 $\mathrm{BFO}$ 박막에서 에피탁시 변형을 통해 격자 구조를 점진적으로 왜곡 시켜 유사-정방정계 및 유사 능명정계(rhombohedral-like) 상이 혼합된 박 막을 발견하였다. 또한 $\mathrm{BFO}$ 박막에 변형을 유도한 구조 적 변화를 이론적으로 계산으로 보여줌과 동시에 이를 투과전자현미경을 통해 원자 분해능의 이미지를 통해 결정 구조의 차이를 명확하게 보여주었다(Fig. 9). ${ }^{54)}$

이러한 연구들은 $\mathrm{BFO}$ 박막 합성 기술과 함께 변형 엔 지니어링을 통해 정밀한 특성 제어 및 박막의 미세 구 조 변화와의 관계에 대한 이해를 가능하게 하였다. 고 품질 에피탁시 $\mathrm{BFO}$ 박막을 얻기 위해 $\mathrm{PLD}^{13,55,56)}, r f$ 스 퍼터링 ${ }^{33,57)} \mathrm{MOCVD}^{36,58)}$ 및 $\mathrm{CSD}^{59)}$ 증착 기술을 통해 $\mathrm{SrTiO}_{3}, \mathrm{DyScO}_{3}$ 및 $\mathrm{LaAlO}_{3}$ 을 포함한 다양한 기판에 증 착되었다. 대부분의 연구에서 이러한 박막의 결정도와
전반적인 품질은 $\mathrm{X}$ 선 회절(XRD)을 통해 확인되었다. (001), (101), (111) $\mathrm{SrTiO}_{3}$ 기판위에 스퍼터링 사용하 여 에피탁시한 $\mathrm{BFO}$ 을 증착하였으며, 이를 통해 향상된 분극 특성을 보고하였다. ${ }^{33)}$ Fig. 10에 보여지듯이 XRD $\theta-2 \theta$ 및 $\mathrm{P}-\mathrm{E}$ hysteresis loop 측정을 통해 $\mathrm{BFO}$ 의 고 품질 에피탁시 박막을 확인할 수 있었다.

지금까지 에피탁시 $\mathrm{BFO}$ 박막의 구조, 강유전성, 자기 및 자기-전기적 특성 및 성장을 연구하기 위해 많은 실 험이 수행이 되었으며, 이를 바탕으로 $\mathrm{BFO}$ 다강체에 대 한 이해에도 큰 진전이 있었다.

\section{$\mathrm{BiMnO}_{3}(\mathrm{BMO})$ 박막}

$\mathrm{BFO}$ 와 유사한 다강체 재료인 $\mathrm{BMO}$ 는 $\mathrm{Bi} 6 \mathrm{~s}^{2}$ long pair의 의한 강유전성과 $\mathrm{Mn}^{3+}$ 이온 사이의 superexchange 상호 작용에 의한 강자성을 지니고 있 


\section{특 집 ㅁㅃ 여홍구}
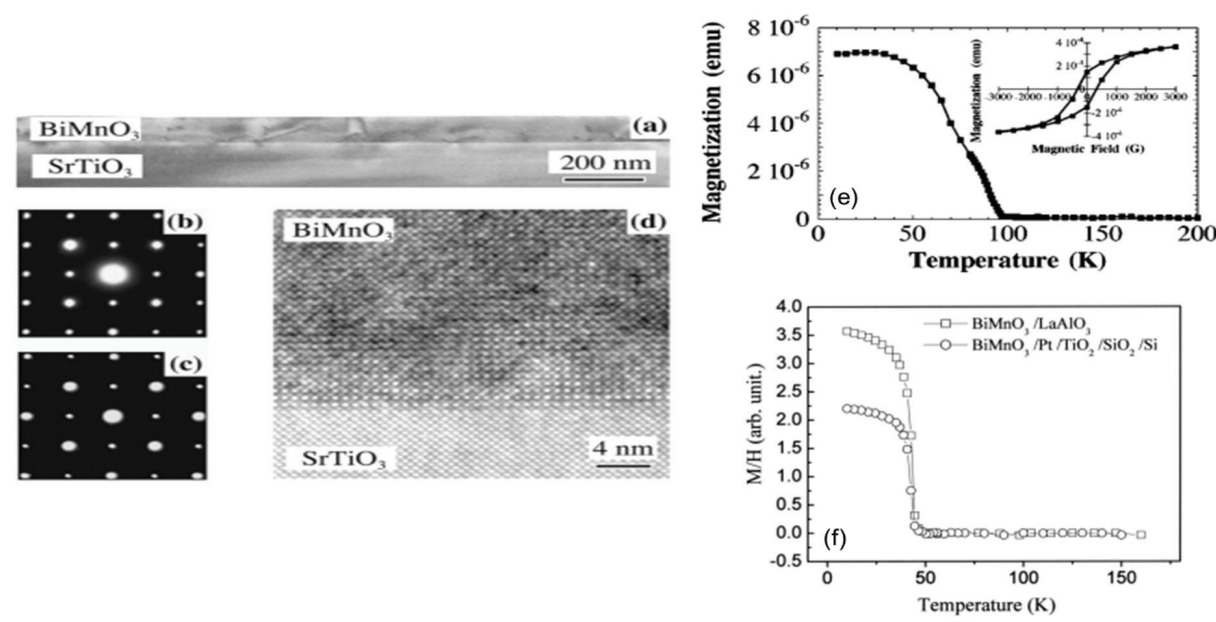

Fig. 11. XTEM images and SAED patterns along the [010] zone axis of the (100) $\mathrm{SrTiO}_{3}$ substrate of the same $\mathrm{BiMnO}_{3}$ film (a) $\mathrm{Low}$ magnification image, (b) SAED pattern film $\mathrm{BiMnO}_{3}$ film, (c) SAED pattern from $\mathrm{SrTiO}_{3}$ substrate, and (d) HRTEM image of the film/substrate interface. (e) Magnetization curve of the $\mathrm{BiMnO}_{3}$ film on (100) $\mathrm{SrTiO}_{3}$ cooled under no applied magnetic field. The inset shows the ferromagnetic hysteresis loop at $T=5 \mathrm{~K}$. Adapted from dos Santos et al. Appl. Phys. Lett. 2004;84;91 with permission of American Institute of Physics [62] ( $f$ ) Temperature dependence of magnetization of the epitaxial $(100) \mathrm{BiMnO}_{3}$ film and the preferentially (111) oriented $\mathrm{BiMnO}_{3}$ film. Adapted from Son et al. Appl. Phys. Lett. 2004;84;4971 with permission of American Institute of Physics [63]

다. 이러한 $\mathrm{BMO}$ 다강체는 벌크 시편 성장은 일반적 으로 대기압에서 안정되지 않는 반면 안정적인 성장을 위해 높은 온도( 1000K)와 압력( $6 \mathrm{GPa})$ 이 필요하 다. ${ }^{60,61)}$ 이러한 $\mathrm{BMO}$ 상은 에피탁시한 변형, 격자 부적 응 변형(lattice misfit strain) 그리고 계면 에너지를 통 해 대기압의 상온에서 안정화 된 박막 성장의 가능함을 보여주고 있다.

비록 성공적인 박막 성장의 증착 조건은 매우 제한적 이나, 처음으로 보고되어진 $\mathrm{BMO}$ 박막은 $\mathrm{PLD}$ 을 이용하 여 968K 온도의 (001) $\mathrm{SrTiO}_{3}$ 기판에서 이루어졌다. ${ }^{62)}$ $\mathrm{X}$-선 회절 및 투과 전자 현미경(TEM)을 통한 구조 분 석을 통해 단사정 $\mathrm{BMO}$ 박막이 성장을 확인하였으며, 강자성 전이 온도 $\left(\mathrm{T}_{\mathrm{c}}\right)$ 인 경우 $97 \mathrm{~K}$ 로 기존의 벌크에서 보 여진 $\mathrm{T}_{\mathrm{c}}=105 \mathrm{~K}$ 보다 살짝 낮았다(Fig. 11(e)). 이는 박 막의 변형 또는 조성비가 벗어나는 등의 가능성을 언급 하였다. 이러한 $\mathrm{BMO}$ 박막의 강자성 전이 온도가 기판 에 따라 다르며 이론적으로 격자 상수가 $3.962 \AA$ 인 벌 크 $\mathrm{BMO}$ 와 $\sim 4.3 \%$ 가 격자 불일치를 가진 $\mathrm{LaAlO}_{3}$ 기판 위에 PLD 방법으로 증착된 $100 \mathrm{~nm} \mathrm{BMO}$ 박막인 경우
$50 \mathrm{~K}$ 에서 강자성 전이를 보였다(Fig. $11(\mathrm{f}))^{63)}$

\section{그 밖에 단일상 다강체 박막}

$\mathrm{Bi}$ 기반의 페로브스카이트 및 육방정계(hexagonal) 망간염(manganite) 외에도 다강성 특성을 나타내는 orhtoferrites $\left(\mathrm{h}-\mathrm{RFeO}_{3}, \mathrm{R}=\mathrm{Y}, \mathrm{Sc}\right.$, and $\left.\mathrm{Ho}-\mathrm{Lu}\right)$ 에 대한 관심이 증가하고 있다. $\mathrm{DyFeO}_{3}$ 와 $\mathrm{LuFeO}_{3}$ 가 그와 같은 구조를 가진 전형적인 재료이다. ${ }^{64-66)} \mathrm{LuFeO}_{3}$ 박막 인 경우 새로운 형태의 상온 다강성을 가지고 있으나 아 직까지 다강체의 특성 및 여러 변수에 대한 상호간의 관 계에 대한 충분한 연구가 풍족한 실정이다.

앞서 언급한 다강체 물질 외에도 $\mathrm{A}$ 양이온 자리에 lone pairs이 있고 B 자리에 자기 전이 금속이 있는 다 양한 다강성 박막이 연구되고 있다. $\mathrm{BiCrO}_{3}$ 는 2002 년 예측 ${ }^{67)}$ 이후 (001) $\mathrm{LaAlO}_{3},(001) \mathrm{SrTiO}_{3}$ 및 (110) $\mathrm{NaGaO}_{3}$ 와 다양한 기판에 $\mathrm{PLD}$ 을 통해 $\mathrm{BiCrO}_{3}$ 박막을 성장 시켰으며, 기판의 격자 불일치(lattice mismatch) 로 인해 격자 길이가 다른 $\mathrm{BiCrO}_{3}$ 박막이 각각 성장되었 다. 이러한 $\mathrm{BiCrO}_{3}$ 박막은 $120 \mathrm{~K}$ 의 Curie 온도에서 약 

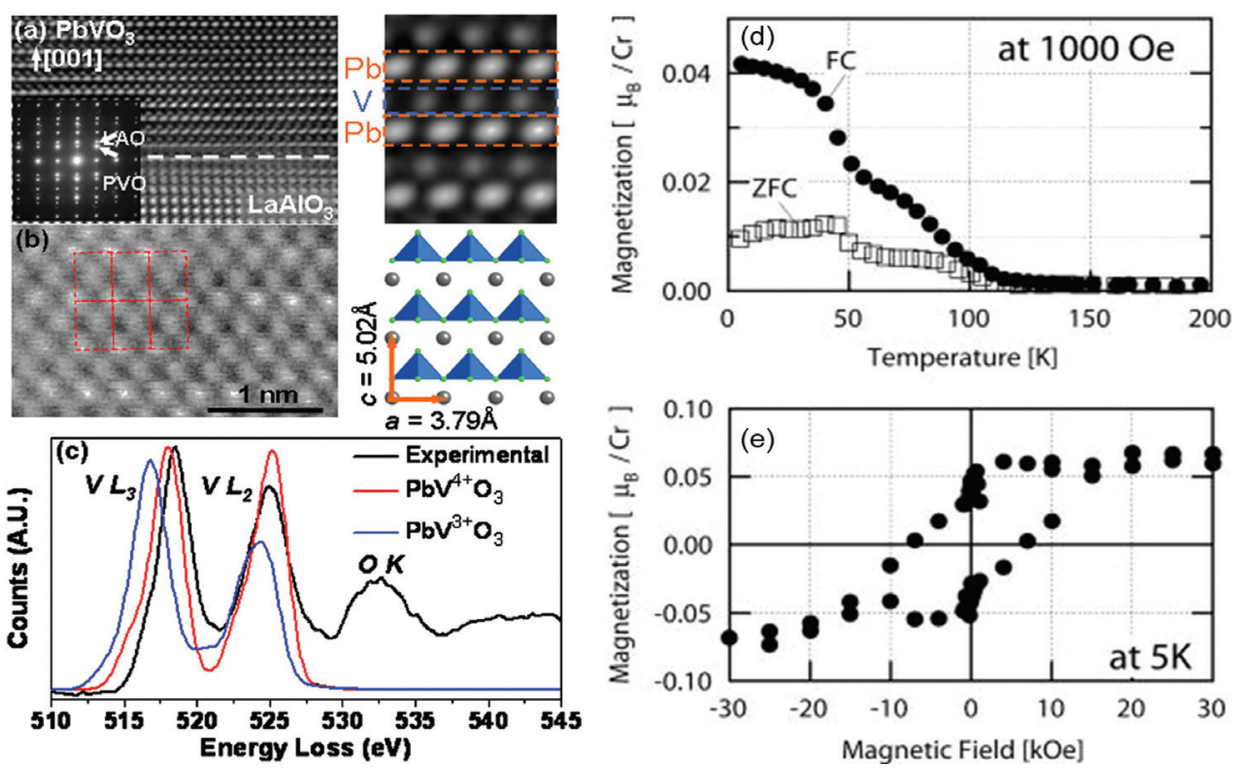

Fig. 12. (Color online) Electron microscopy of PVO films on LAO(001) substrates. (a) Cross-section HRTEM image of the PVO/LAO interface. The inset shows the SAED confirming the in-plane registry of film and substrate. Highly magnified HRTEM image and illustration also illustrate the highly distorted PVO structure. (b) STEM image of PVO down the [010] zone axis. (c) Experimental EELS spectra for PVO along with simulated EELS spectra for $V-L$ edge in PVO assuming possible $V^{4+}$ and $V^{3+}$ oxidation states. Adapted from Martin et al. Appl. Phys. Lett. 2007;90;062903 with permission of American Institute of Physics [69]. Temperature dependent magnetization curves (d) and a magnetic hysteresis curve (5K) (e) of a $\mathrm{BiCrO}_{3}$ thin film fabricated on a $\mathrm{LaAlO}_{3}$ (001) substrate. Adapted from Murakami et al. Appl. Phys. Lett. 2006;88;152902 with permission of American Institute of Physics [68].

한 강유전성과 반강자성/약강자성을 나타내는 것으로 보고되었으며. ${ }^{68)}$ 이러한 초기 $\mathrm{BiCrO}_{3}$ 박막 연구에서 실 온에서 상온에서 압전성 및 tunable 유전 상수를 보여 주었다.

또 다른 단일상 다강성 재료로 $\mathrm{PbVO}_{3}(\mathrm{PVO})$ 가 있 다. ${ }^{69)}$ 2007년 미국의 버클리 대학의 연구 그룹에서 $\mathrm{PbVO}_{3}$ 박막을 $\mathrm{PLD}$ 증착법을 통해 $(001) \mathrm{LaAlO}_{3}(\mathrm{LAO})$, $\mathrm{LaAlO}_{3} /(100) \mathrm{Si}, \quad(110) \mathrm{NdGaO}_{3},(001)\left(\mathrm{La}_{0.18} \mathrm{Sr}_{0.82}\right)$ $\left(\mathrm{Al}_{0.59} \mathrm{Ta}_{0.41}\right) \mathrm{O}_{3},(001) \mathrm{SrTiO}_{3}$ 와 같은 다양한 기판들 위 에 성장 시켰다. (001) $\mathrm{LaAlO}_{3}$ 기판 위에 $\mathrm{Pb}_{2} \mathrm{~V}_{2} \mathrm{O}_{7}$ 타켓 을 이용하여 고온이 가해지고 있는 기판에 $\left(450 \sim 650^{\circ} \mathrm{C}\right.$ ) 증착한 결과 $\mathrm{PbVO}_{3}$ 박막에서는 c/a 격자 비가 1.32 인 정방정계 페로브스카이트 상을 가짐을 보였다(Fig.12). 이 후 연구를 통해 $\mathrm{PbVO}_{3}$ 다강체 박막의 압전성과 반강 자성을 $130 \mathrm{~K}$ 에서 보여짐을 확인하였다. ${ }^{70)}$

2006년도에는 Fennie와 Rabe는 강유전성 강자성체
에 대한 새로운 연구를 시작 하였다. ${ }^{71)}$ 강유전성도 강자 성도 아닌 자기적으로 정렬된 열역학적으로 안정된 절 연체를 에피탁시 변형(epitaxy strain)을 사용하여 강 유전성 강자성체로 변화됨을 보고하였다. 특히 변형된 $\mathrm{EuTiO}_{3}$ 에서 강한 강자성 $\left(\mathrm{M}_{\mathrm{s}} \sim 7 \mu_{\mathrm{B}} / \mathrm{Eu}\right)$ 과 강한 강유 전성 $\left(\mathrm{P}_{\mathrm{s}} \sim 10 \mu \mathrm{C} / \mathrm{cm}^{2}\right)$ 을 동시에 나타낼 것으로 예측하 였다. 특히 이러한 예측 값은 기존에 그 어떤 강유전성 과 강자성의 동시에 지닌 단일상 다강체보다 수십 배 높 았다. 하지만 이러한 이론적 결과와 부합된 연구 결과에 대한 보고가 한동안 없는 가운데, 2010년 반응성 $\mathrm{MBE}$ 방법으로 $(110) \mathrm{DyScO}_{3}$ 기판 위에 증착된 $+1.1 \%$ 쌍축 인장력이 가해진 $\mathrm{EuTiO}_{3}$ 에서 $\sim 29 \mu \mathrm{C} / \mathrm{cm}^{2}$ 자발 분극 $\left(\mathrm{P}_{\mathrm{s}}\right)$ 을 가짐을 보고하였다. ${ }^{72)}$

이외에 관심 가질만한 단일상 다강체 물질로는 $\mathrm{BiCoO}_{3}$ 가 있다. 실험과 함께 이론적 접근과 통해 벌크 $\mathrm{BiCoO}_{3}$ 에서 $150 \mu \mathrm{C} / \mathrm{cm}^{2}$ 이상의 거대한 분극에 가질 수 


\section{특 집 ㅁㅃ 여홍구}

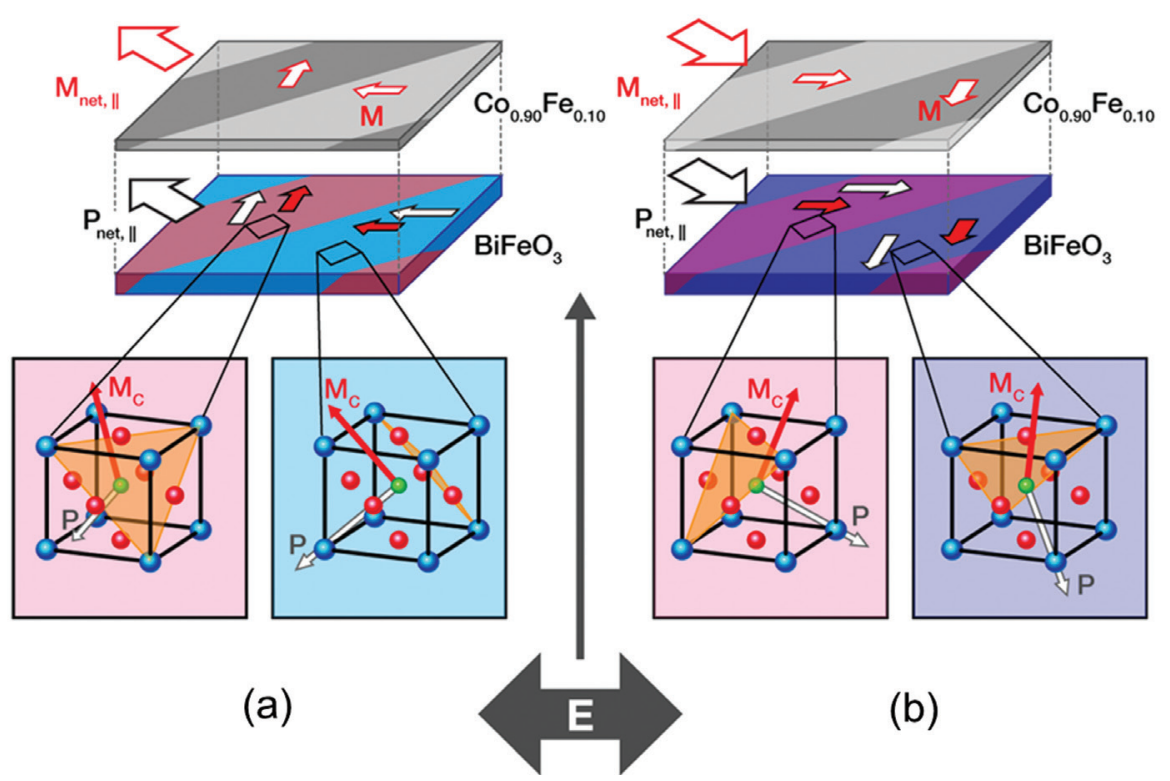

Fig. 13. Reversing the magnetization and polarization of the $\mathrm{BiFeO}_{3} / \mathrm{CO}_{0.9} \mathrm{Fe}_{0.1}$ heterostructure by an electric field pulse. $P$ and $M_{C}$ denote the polarization and the canted magnetization of the $\mathrm{BiFeO}_{3}$ film in relation to the (111) plane of the respective ferroelectric domain. $M$ denotes the magnetization of the corresponding $\mathrm{Co}_{0.9} \mathrm{Fe}_{0.1}$ domain. $P_{\text {net } / \text {, and }} M_{\text {net } / / \text {, indicate the in-plane }}$ component of the net polarization and magnetization of the heterostructure when averaging across the domains. The reversal between the structures in (a) and (b) is achieved by applying the electric field pulse $E$ as shown. Adapted from Heron et al. Phys. Rev. Lett. 2011;107;217202 with permission of American Physical Society [76].

있음을 예측 하였으며, 이는 연구자들에게 안정된 단일 상의 $\mathrm{BiCoO}_{3}$ 박막을 합성하고자 하는 동기를 부여하였 다. ${ }^{73,74)}$

\section{3. 다강성 박막의 응용분야 및 결론}

오늘날 다강체 연구에서 가장 큰 화두는 상온에서 다 강성의 특성을 이용하여 작동 가능한 디바이스로 개 발이 가능한가 여부이다. 이는 상온에서 작동하는 센 서, 공진기, 필터, 위상 천이기, 비휘발성 메모리, 트 랜지스터 등 다양한 기술로 이어질 수 있다. 하지만 잘 알려진 강유전-강자성을 동시에 지니는 다강체의 직 접 결합(direct-coupling)은 실제로 응용분야에 적용 하기에는 여전히 충분치 않기에 또 다른 접근 방법으 로 다강체 복합소재를 활용하는 연구들이 진행되고 있 다. 그 중 하나가 반강자성과 강유전성과 간접 결합 (indirect-coupling)을 통해 전기적으로 제어가 가능한 exchange bias를 이용하는 방식이다. 실질적으로 이를 위해서는 다강체층 아래의 강자성층이 결합된 bilayer heterostructure 형태가 제안된다. $\mathrm{Wu}$ 와 그의 동료들 의 연구에서 강자성체인 $\mathrm{La}_{1-\mathrm{x}} \mathrm{Sr}_{\mathrm{x}} \mathrm{MnO}_{3}$ 와 다강체 $\mathrm{BFO}$ 박막을 이용하여 전기적 제어를 통한 exchange bias을 보여주었다. ${ }^{75)}$ 이러한 반강자성과 강유전성과의 결합에 서는 반강자성 방향은 영구적이며 비휘발적인 반면, 반 강자성체와 인접한 강자성체의 결합에서는 외부 전기장 을 통해 강자성의 변화가 가능하다. ${ }^{76)}$

이러한 특성을 이용하여 기본적으로 자기 기록 헤드 등에 사용할 수 있을 뿐만 아니라, 낮은 전력이 소모되 는 메모리(memory) 및 로직 장치(logic device)에 적용 가능성을 보여주고 있다. 그 밖에도 물리적으로 결합된 강유전성-강자성 또는 강자성-다강체 복합물에서 고주 파수 자기-전기 응답이 가능한 장치의 가능성도 고려된 다. 이는 전기장으로 조정이 가능한 무선 주파수 $(\mathrm{RF}) /$ 마이크로파 신호 처리 장치 및 자기장 센서, 자기-전기 
랜덤 액세스 메모리(magnetoelectric random access memory)등의 분야 적용 가능성을 열어주었다. ${ }^{77)}$

여러가지 흥미로운 특성을 보여주는 자기-전기 다강 성 박막은 오늘날까지 많은 연구자들의 의해 재료의 합 성, 특성 및 이론적 측면에 많은 진전이 있었다. 하지만 다강성 재료가 지닌 고유의 복잡성 및 구조적 한계로 인 해 실제 응용 제품으로 적용하기에는 여전히 많은 어려 움이 있다, 비록 몇 가지 흥미로운 연구 결과도 보고되 어 오고 있으나 상온에서 강한 자기-전기 효과를 가진 재료 개발이 여전히 요구되고 있다. 그리고 이러한 목표 를 성취 하기 위해 지속적이고 도전적인 연구들이 학교, 연구소 및 기업과 같은 다양한 기관에서 진행된다면, 미 래에는 박막 성장 기술의 발전과 함께 새로운 박막 다강 체 개발의 기회가 확대 될 것으로 전망된다.

\section{Acknowledgement}

This research was supported by Basic Science Research Program through the National Research Foundation of Korea(NRF) funded by the Ministry of Education (2019R111A1A01058974)

\section{REFERENCES}

1. T. Jia, H. Kimura, Z. Cheng, \& H. Zhao, "Switching of both local ferroelectric and magnetic domains in multiferroic $\mathrm{Bi}_{0.9} \mathrm{La}_{0.1} \mathrm{FeO}_{3}$ thin film by mechanical force," Scientific reports, 6 [1] 1-9 (2016).

2. Y. Tokura, "Multiferroics - toward strong coupling between magnetization and polarization in a solid" Journal of Magnetism and Magnetic Materials, 310 [2] 1145-1150 (2007).

3. N. A. Spaldin, \& R. Ramesh, "Advances in magnetoelectric multiferroics," Nature materials, 18 [3] 203-212 (2019).

4. L. W. Martin, Y. H. Chu, \& R. J. M. S. Ramesh, "Advances in the growth and characterization of magnetic, ferroelectric, and multiferroic oxide thin films," Materials Science and Engineering: R: Reports, 68 [4-6], 89-133 (2010).

5. Y. Tokura, "Multiferroics - toward strong coupling between magnetization and polarization in a solid," Journal of Magnetism and Magnetic Materials, 310 [2] 1145-1150 (2007).

6. W. Eerenstein, M. Wiora, J. L. Prieto, J. F. Scott, \& N. D. Mathur, "Giant sharp and persistent converse magnetoelectric effects in multiferroic epitaxial heterostructures," Nature materials, 6 [5] 348-351 (2007).

7. M. Gajek, M. Bibes, S, Fusil, K. Bouzehouane, J. Fontcuberta, A. Barthélémy, \& A. Fert, "Tunnel junctions with multiferroic barriers," Nature materials, 6 [4] 296-302 (2007).

8. G. T. Hwang, H. Song, J. Jang, J. Ryu, \& W. H. Yoon, "Sensing of ultra-low magnetic field by magnetoelectric (ME) composites(in Korean)," Ceramist, 23 [1] 38-53 (2020).

9. D. G. Schlom, J. H. Haeni, J. Lettieri, C. D. Theis, W. Tian, J. C. Jiang, \& X. Q. Pan, "Oxide nanoengineering using MBE," Materials Science and Engineering: B, 87 [3] 282-291 (2001).

10. C. Michel, J. M. Moreau, G. D. Achenbach, R. Gerson, \& W. J. James, "The atomic structure of $\mathrm{BiFeO}_{3}$," Solid State Communications, 7 [9] 701-704 (1969).

11. J. D. Bucci, B. K. Robertson, \& W. J. James, "The precision determination of the lattice parameters and the coefficients of thermal expansion of $\mathrm{BiFeO}_{3}$," Journal of Applied Crystallography, 5 [3] 187-191 (1972).

12. J. R. Teague, R. Gerson, \& W. J. James, "Dielectric hysteresis in single crystal $\mathrm{BiFeO}_{3}$," Solid State Communications, 8 [13] 1073-1074 (1970).

13. J. Wang, J. B. Neaton, H. Zheng, V. Nagarajan, S. B. Ogale, B. Liu, D. Viehland, V. Vaithyanathan, D. G. Schlom, U. V. Waghmare, N. A. Spaldin, K. M. Rabe, M. Wuttig, R. Ramesh, "Epitaxial $\mathrm{BiFeO}_{3}$ multiferroic thin film heterostructures," Science, 299 [5613] 17191722 (2003).

14. C. J. Fennie, and M. R. Karin, "Magnetic and electric phase control in epitaxial $\mathrm{EuTiO}_{3}$ from first principles," Physical review letters 97 [26] 267602 (2006).

15. A. De Bonis, \& R. Teghil, "Ultra-short pulsed laser 
deposition of oxides, borides and carbides of transition elements," Coatings, 10 [5] 501 (2020).

16. G. Z. Yang, H. B. Lu, F. Chen, T. Zhao, \& Z. H. Chen, "Laser molecular beam epitaxy and characterization of perovskite oxide thin films," Journal of crystal growth, 227 929-935 (2001).

17. S. B. Ogale, (Ed.). "Thin films and heterostructures for oxide electronics; Chapter 12." Springer Science \& Business Media 2006.

18. M. Huijben, L. W. Martin, Y.-H. Chu, M. B. Holcomb, P. Yu, G. Rijnders, D. H. A. Blank, and R. Ramesh, "Critical thickness and orbital ordering in ultrathin $\mathrm{La}_{0.7} \mathrm{Sr}_{0.3} \mathrm{MnO}_{3}$ films," Phys. Rev. B 78 [9] 094413 (2008).

19. D. H. Kim, H. N. Lee, M. D. Biegalski, \& H. M. Christen, "Large ferroelectric polarization in antiferromagnetic $\mathrm{BiFe}_{0.5} \mathrm{Cr}_{0.5} \mathrm{O}_{3}$ epitaxial films," Applied physics letters, 91 [4] 042906 (2007).

20. H. Koinuma, M. Kawasaki, S. Ohashi, M. Lippmaa, N. Nakagawa, M. Iwasaki, \& X. G. Qiu, "Nucleation and growth control in pulsed laser epitaxy of oxide thin films," (pp. 153-160) in Superconducting and Related Oxides: Physics and Nanoengineering III Vol. 3481, International Society for Optics and Photonics, (1998).

21. P. Chen, S. Y. Xu, J. Lin, C. K. Ong, \& D. F. Cui, "Angle-resolved X-ray photoelectron spectroscopy of topmost surface for $\mathrm{LaNiO}_{3}$ thin film grown on $\mathrm{SrTiO}_{3}$ substrate by laser molecular beam epitaxy," Applied surface science, 137 [1-4] 98-102 (1999).

22. C. Webb, S.-L. Weng, J. N. Eckstein, N. Missert, K. Char, D. G. Schlom, E. S. Hellman, M. R. Beasley, A. Kapitulnik, and J. S. Harris Jr. "Growth of high $\mathrm{T}_{\mathrm{c}}$ superconducting thin films using molecular beam epitaxy techniques," Applied physics letters, 51 [15] 1191-1193 (1987).

23. K. Endo, S. Saya, S. Misawa, \& S. Yoshida, "Preparation of yttrium barium copper oxide superconducting films by metalorganic molecular beam epitaxy," Thin Solid Films, 206 [1-2] 143-145 (1991).

24. B. Jalan, R. Engel-Herbert, N. J. Wright, S. Stemmer, "Growth of high-quality $\mathrm{SrTiO}_{3}$ films using a hybrid molecular beam epitaxy approach," J Vac Sci Technol A 27 461-4 (2009).
25. K. Wasa, M. Kitabatake, H. Abachi, Thin Film Materials Technology-Sputtering of Compound Materials; William Andrew Publishing, Norwich, NY, 2004.

26. H. Adachi, T. Mitsuyu, O. Yamazaki, K. Wasa, "Ferroelectric $(\mathrm{Pb}, \mathrm{La})(\mathrm{Zr}, \mathrm{Ti}) \mathrm{O}_{3}$ epitaxial thin films on sapphire grown by $r f$-planar magnetron sputtering," J. Appl. Phys. 60736 (1986).

27. H. Ishiwara, M. Okuyama, \& Y. Arimoto, Ferroelectric random access memories: fundamentals and applications; Vol. 93, Springer Science \& Business Media 2004.

28. J. Im, O. Auciello, P. K. Baumann, S. K. i, D. Y. Kaufman, A. R. Krauss, "Composition-control of magnetron-sputter-deposited $\left(\mathrm{Ba}_{\mathrm{x}} \mathrm{Sr}_{1-\mathrm{x}}\right) \mathrm{Ti}_{1+\mathrm{y}} \mathrm{O}_{3+\mathrm{z}}$ thin films for voltage tunable devices," Appl. Phys. Lett. 76625 (2000).

29. S. E. Moon, T. K. Song, S. B. Back, S.-I. Kwun, J.-G. Yoon, J. S. Lee, "Controlled growth of a-/b-and c-axis oriented epitaxial $\mathrm{SrBi}_{2} \mathrm{Ta}_{2} \mathrm{O}_{9}$ ferroelectric thin films," Appl. Phys. Lett. 75 [18] 2827-2829 (1999).

30. T. K. Song, J. K. Lee, \& H. J. Jung, "Structural and ferroelectric properties of the c-axis oriented $\mathrm{SrBi}_{2} \mathrm{Ta}_{2} \mathrm{O}_{9}$ thin films deposited by the radiofrequency magnetron sputtering," Applied physics letters, 69 [25] 3839-3841 (1996).

31. J. Schwarzkopf, \& R. Fornari, "Epitaxial growth of ferroelectric oxide films," Progress in crystal growth and characterization of materials, 52 [3] 159-212 (2006).

32. N. Fujimura, T. Ishida, T. Yoshimura, \& T. Ito, "Epitaxially grown $\mathrm{YMnO}_{3}$ film: New candidate for nonvolatile memory devices," Applied physics letters, 69 [7] 1011-1013 (1996).

33. R. R. Das, D. M. Kim, S. H. Baek, C. B. Eom, F. Zavaliche, S. Y. Yang, R. Ramesh, Y. B. Chem, X. Q. Pen, X. Ke, M. S. Rzchowski, and S. KStreiffer, "Synthesis and ferroelectric properties of epitaxial $\mathrm{BiFeO}_{3}$ thin films grown by sputtering," Applied physics letters, 88 [24] 242904 (2006).

34. Y. Krockenberger, A. Ikeda, K. Kumakura, \& H. Yamamoto, "Infinite-layer phase formation in the $\mathrm{Ca}_{1-\mathrm{x}} \mathrm{Sr}_{\mathrm{x}} \mathrm{CuO}_{2}$ system by reactive molecular beam epitaxy," Journal of Applied Physics, 124 [7] 073905 (2018).

35. H. G. Yeo, T. Xue, S. Roundy, X. Ma, C. Rahn, \& S. 
Trolier-McKinstry, "Strongly (001) oriented bimorph PZT film on metal foils grown by $r f$-sputtering for wrist-worn piezoelectric energy harvesters," Advanced Functional Materials, 28 [36] 1801327 (2018).

36. S. Y. Yang, F. Zavaliche, L. Mohaddes-Ardabili, V. Vaithyanathan, D. G. Schlom, Y. J. Lee, Y. H. Chu, M. P. Cruz, Q. Zhan, T. Zhao, and R. Ramesh, "Metalorganic chemical vapor deposition of lead-free ferroelectric $\mathrm{BiFeO}_{3}$ films for memory applications," Applied physics letters, 87 [10] 102903 (2005).

37. M. K. Singh, Y. Yang, \& C. G. Takoudis, "Synthesis of multifunctional multiferroic materials from metalorganics," Coordination Chemistry Reviews, 253 [23-24] 2920-2934 (2009).

38. J. H. Choi, C. D. Pham, J. P. Chang, "Engineered multiferroic PZT-CFO and BFO-CFO thin films for large magnetoelectric coefficient by atomic layer deposition," Presented at 2011 AIChE annual meeting, Minneapolis, MN; Wednesday October 19, 2011.

39. K. Uusi-Esko K, M. Karppinen "Extensive series of hexagonal and orthorhombic $\mathrm{RMnO}_{3}(\mathrm{R}=\mathrm{Y}$, $\mathrm{La}, \mathrm{Sm}, \mathrm{Tb}, \mathrm{Yb}, \mathrm{Lu})$ thin films by atomic layer deposition,"Chem. Mater. 23 1835-40 (2011).

40. P. A. Salvador, T. D. Doan, B. Mercey, \& B. Raveau, "Stabilization of $\mathrm{YMnO}_{3}$ in a perovskite structure as a thin film," Chemistry of materials, 10 [10] 2592-2595 (1998).

41. D. Ito, N. Fujimura, T. Yoshimura, \& T. Ito," Ferroelectric properties of $\mathrm{YMnO}_{3}$ epitaxial films for ferroelectric-gate field-effect transistors," Journal of Applied Physics, 93 [9] 5563-5567 (2003).

42. X. Martí, F. Sánchez, D. Hrabovsky, L. Fàbrega, A. Ruyter, J. Fontcuberta, V. Laukhin, V. Shkumryev. M. V. Garcia-Cuences, C. Ferrater, M. Vareia, A. Vilià, U. Lüders, \& J. F. Bobo, "Exchange biasing and electric polarization with $\mathrm{YMnO}_{3}$," Applied physics letters, 89 [3] 032510 (2006).

43. K. Suzuki, D. Fu, K. Nishizawa, T. Miki, K. Kato, "Ferroelectric property of alkoxy-derived $\mathrm{YMnO}_{3}$ argon,” Jpn. J. Appl. Phys. 425692 (2003).

44. J. Dho, C. W. Leung, J. L. MacManus-Driscoll, \& M. G. Blamire, "Epitaxial and oriented $\mathrm{YMnO}_{3}$ film growth by pulsed laser deposition," Journal of crystal growth, 267[3-4] 548-553 (2004).
45. A. Posadas, J.-B. Yau, and C. H. Ahn, J. Han, S. Gariglio, K. Johnston and K. M. Rabe, \& J. B. Neaton, "Epitaxial growth of multiferroic $\mathrm{YMnO}_{3}$ on GaN," Applied physics letters, 87 [17] 171915 (2005).

46. S. Imada, S. Shouriki, E. Tokumitsu, \& H. Ishiwara, "Epitaxial growth of ferroelectric $\mathrm{YMnO}_{3}$ thin films on Si (111) substrates by molecular beam epitaxy," Jpn. J. Appl. phys., 37 [12R] 6497 (1998).

47. D. Kim, D. Klingensmith, D. Dalton, V. Olariu, F. Gnadinger, M. Rahman, A. Mahmud, T. S. Kalkur, "C-axis oriented $\mathrm{MOCVD} \mathrm{YMnO}_{3}$ thin film and its electrical characteristics in FeTRAM,". Integr. Ferroelectr. 6875 (2004).

48. J. M. Moreau, C. Michel, R. Gerson, \& W. J. James, "Ferroelectric $\mathrm{BiFeO}_{3}$ X-ray and neutron diffraction study," Journal of Physics and Chemistry of Solids, 32 [6] 1315-1320 (1971).

49. D. Lebeugle, D. Colson, A. Forget, \& M. Viret, "Very Large Spontaneous Electric Polarization in $\mathrm{BiFeO}_{3}$ Single Crystals at Room Temperature and its Evolution Under Cycling Fields," Appl. Phys. Lett. 91 [2] 022907 (2007).

50. M. B. Holcomb, L. W. Martin, A. Scholl, Q. He, P. Yu, C.-H. Yang, S. Y. Yang, P.-A. Glans, M. Valvidares, M. Huijben, J. B. Kortright, J. Guo, Y.-H. Chu, and R. Ramesh, "Probing the evolution of antiferromagnetism in multiferroics," Physical Review B, 81 [13] 134406 (2010).

51. Y. H. Chu, M. P. Cruz, C. H. Yang, L. W. Martin, P. L. Yang, J. X. Zhang, K. Lee, P. Yu, L.-Q. Chen, \& R. Ramesh, "Domain control in multiferroic $\mathrm{BiFeO}_{3}$ through substrate vicinality," Advanced materials, 19 [18] 2662-2666 (2007).

52. L. W. Martin, Y.-H. Chu, M. B. Holcomb, M. Huijben, P. Yu, S.-J. Han, D. Lee, S. X. Wang, and R. Ramesh, "Nanoscale control of exchange bias with $\mathrm{BiFeO}_{3}$ thin films," Nano letters, 8 [7] 2050-2055 (2008).

53. S. K. Streiffer, C. B. Parker, A. E. Romanov, M. J. Lefevre, L. Zhao, J. S. Speck, W. Pompe, C. M. Foster, and G. R. Bai, "Domain patterns in epitaxial rhombohedral ferroelectric films. I. Geometry and experiments," J. Appl. Phys. 832742 (1998).

54. R. J. Zeches, M. D. Rossell, J. X. Zhang, A. J. Hatt, Q. He, C. H. Yang, \& R. Ramesh, "A strain-driven morphotropic phase boundary in $\mathrm{BiFeO}_{3}$," Science, 326 [5955] 977-980 (2009). 
55. G. W. Pabst, L. W. Martin, Y. H. Chu, \& R. Ramesh, "Leakage mechanisms in $\mathrm{Bi} \mathrm{FeO}_{3}$ thin films. Applied physics letters, 90 [7] 072902 (2007).

56. V. R. Palkar, J. John, \& R. Pinto, “Observation of saturated polarization and dielectric anomaly in magnetoelectric $\mathrm{BiFeO}_{3}$ thin films," Applied physics letters, 80 [9) 1628-1630 (2002).

57. Y. H. Lee, C. S. Liang, \& J. M. Wu, "Crystal growth and characterizations of highly oriented $\mathrm{BiFeO}_{3}$ thin films," Electrochemical and Solid State Letters, 8 [11] F55 (2005).

58. R. Ueno, S. Okaura, H. Funakubo, \& K. Saito, "Crystal structure and electrical properties of epitaxial $\mathrm{BiFeO}_{3}$ thin films grown by metal organic chemical vapor deposition,” Jpn. J. Appl. phys., 44 [9L] L1231 (2005).

59. S. K. Singh, Y. K. Kim, H. Funakubo, \& H. Ishiwara, "Epitaxial $\mathrm{BiFeO}_{3}$ thin films fabricated by chemical solution deposition," Applied physics letters, 88 [16] 162904 (2006).

60. F. Sugawara, S. Iida, "New magnetic perovskites $\mathrm{BiMnO}_{3}$ and $\mathrm{BiCrO}_{3}$," J. Phys. Soc. Jpn. 20 [8] 1529 (1965).

61. T. Atou, H. Chiba, K. Ohoyama, Y. Yamaguchi, Y. Syono, "Structure determination of ferromagnetic perovskite $\mathrm{BiMnO}_{3}$," J Solid State Chem. 145 [2] 639-42 (1999).

62. A. F. Moreira dos Santos, A. K. Cheetham, W. Tian, X. Pan, Y. Jia, N. J. Murphy, J. Lettieri, \& D. G. Schlom, "Epitaxial growth and properties of metastable $\mathrm{BiMnO}_{3}$ thin films," Applied physics letters, 84 [1] 91-93 (2004).

63. J. Y. Son, B. G. Kim, C. H. Kim, \& J. H. Cho, "Writing polarization bits on the multiferroic $\mathrm{BiMnO}_{3}$ thin film using Kelvin probe force microscope," Applied physics letters, 84 [24] 4971-4973 (2004).

64. Z. Y. Zhao, X. Zhao, H. D. Zhou, F. B. Zhang, Q. J. Li, C. Fan, X. F. Sun, and X. G. Li, "Ground state and magnetic phase transitions of orthoferrite DyFeO," Physical Review B, 89 [22] 224405 (2014).

65. Y. Tokunaga, Y. Taguchi, T. Arima, \& Y. Tokura, "Magnetic biasing of a ferroelectric hysteresis loop in a multiferroic orthoferrite," Physical review letters, 112 [3] 037203 (2014).

66. W. Wang, J. Zhao, W. Wang, Z. Gai, N. Balke, M. Chi, H. N. Lee, W. Tian, L. Zhu, X. Cheng,
D. J. Keavney, J. Yi, T. Z. Ward, P. C. Snijders, H. M. Christen, W. Wu, J. Shen, and X. Xu, "Roomtemperature multiferroic hexagonal $\mathrm{LuFeO}_{3}$ films," Physical review letters, 110 [23] 237601 (2013).

67. N. A. Hill, P. Bättig, \& C. Daul, "First principles search for multiferroism in $\mathrm{BiCrO}_{3}$," The Journal of Physical Chemistry B, 106 [13] 3383-3388 (2002).

68. M. Murakami, S. Fujino, S.-H. Lim, C. J. Long, L. G. Salamanca-Riba, M. Wuttig, and I. Takeuchi V. Nagarajan \& A. Varatharajan, "Fabrication of multiferroic epitaxial $\mathrm{BiCrO}_{3}$ thin films," Applied physics letters, 88 [15] 152902 (2006).

69. L. W. Martin, Q. Zhan, Y. Suzuki, R. Ramesh, M. Chi, N. Browning, T. Mizoguchi, \& J. Kreisel, "Growth and structure of $\mathrm{PbVO}_{3}$ thin films," Applied physics letters, 90 [6] 062903 (2007).

70. A. Kumar, L. W. Martin, S. Denev, J. B. Kortright, Y. Suzuki, R. Ramesh, \& V. Gopalan, "Polar and magnetic properties of $\mathrm{PbVO}_{3}$ thin films," Physical Review B, 75 [6] 060101 (2007).

71. C. J. Fennie, \& K. M. Rabe, "Magnetic and electric phase control in epitaxial $\mathrm{EuTiO}_{3}$ from first principles," Physical review letters, 97 [26] 267602 (2006).

72. J. H. Lee, L. Fang, E. Vlahos, X. Ke, Y. W. Jung, L. F. Kourkoutis, J.-W. Kim, P. J. Ryan, T. Heeg, M. Roeckerath, V. Goian, M. Bernhagen, R. Uecker, P. C. Hammel, K. M. Rabe, S. Kamba, J. Schubert, J. W. Freeland, D. A. Muller, C. J. Fennie, P. Schiffer, V. Gopalan, E. Johnston-Halperin \& D. G. Schlom, "A strong ferroelectric ferromagnet created by means of spin-lattice coupling," Nature, 466 [7309] 954-958 (2010).

73. A. A. Belik, S. Iikubo, K. Kodama, N. Igawa, S. Shamota, S. Niitaka, M. Azuma, Y. Shimakawa, M. Takano, F. Izumi, E. Takayama-Muromachi, "Neutron powder diffraction study on the crystal and magnetic structures of $\mathrm{BiCoO}_{3}$," Chem. Mater. 18 [3] 798-803 (2006).

74. Y. Urantani, T. Shishidou, F. Ishii, T. Oguchi, "Firstprinciples predictions of giant electric polarization," Jpn. J. Appl. Phys. 44 [9S] 7130 (2005).

75. S. M. Wu, S. A. Cybart, P. Yu, M. D. Rossell, J. X. Zhang, R. Ramesh, \& R. C. Dynes, "Reversible electric control of exchange bias in a multiferroic fieldeffect device," Nature materials, 9 [9] 756-761(2010). 
76. J. T. Heron, M. Trassin, K. Ashraf, M. Gajek, Q. He, S. Y. Yang, D. E. Nikonov, Y-H. Chu, S. Salahuddin, and R. Ramesh, "Electric-field-induced magnetization reversal in a ferromagnet-multiferroic heterostructure,"
Physical review letters, 107 [21] 217202 (2011).

77. N. A. Spaldin, \& R. Ramesh, "Advances in magnetoelectric multiferroics," Nature materials, 18 [3] 203-212 (2019).

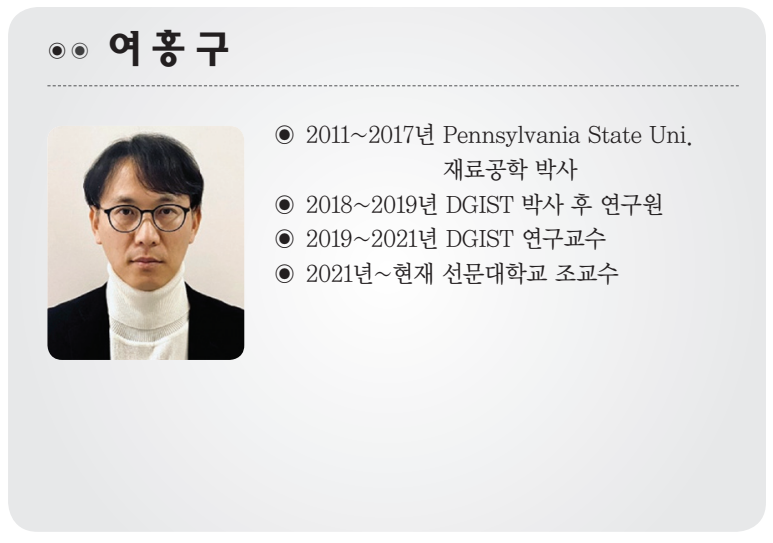

